\title{
Nuclear RNA export
}

\author{
Françoise Stut女 ${ }^{1,3}$ and Michael Rosbash ${ }^{2}$ \\ ${ }^{1}$ Institut de Microbiologie, Centre Hospitalier Universitaire Vaudois, 1011 Lausanne, Switzerland; ${ }^{2}$ Howard Hughes M edical \\ Institute, Department of Biology, Brandeis University, Waltham, M assachusetts 02254 USA
}

RNA export is the process by which RNAs are transported to the cytoplasm after synthesis, processing, and RNP assembly within the nucl eus. The primary focus of this review is mRNA export with particular attention paid to the yeast Saccharomyces cerevisiae. Because there is rather little known about mRN A export in general and even less about yeast mRNA export, our thinking about the problem is influenced by information from other transport processes. These include not only mRN A export in vertebrate systems but al so studies on the export of other RN A substrates and even studies on protein import. Several of these areas of investigation have recently intersected in gratifying ways.

\section{Distinct export pathways for the different classes of RNAs}

Thefirst area of investigation to be discussed is thestudy of RNA export in the Xenopus oocyte system. This approach relies largely on injection experiments, in which different RN A substrates are injected into Xenopus germinal vesicles (nuclei) and cytopl asmic export assayed as a function of time after injection. Pioneering experiments of this kind indicated that the general process of nuclear export is temperature dependent and saturable (Zasloff 1983). Coinjection experiments indicated that different RNA substrates use nonidentical and perhaps entirely different pathways. For example, experiments showed that tRNA, RNA polymerase II gene products (mRNAs and U snRNAs), and ribosomal subunits all used saturable pathways, but any one substrate did not saturate the export of another (Bataille et al. 1990; Jarmolowski et al. 1994; Pokrywka and Goldfarb 1995). Further experiments indicate that $U$ snRN As al so access an export pathway that is shared with both 5S RNA and proteins that carry a specific type of nuclear export signal (NES, see below; Fischer et al. 1995). In higher eukaryotic cells, U snRN As are exported shortly after synthesis. They pick up snRN P proteins and undergo processing events in the cytoplasm, prior to reimport back into the nucleus (Fischer and Lührmann 1990; Hamm et al. 1990a; Fischer et al. 1993). (Export and processing of U snRNAs in yeast cytoplasm has not been demonstrated yet.)

${ }^{3}$ Corresponding author.

E-MAIL fstutz@hola.hospvd.ch; FAX 021-314 4095.

\section{The HIV-1 Rev protein: a prototype RNA export factor}

The second area described is the study of regulated RN A export in viral systems and the function of the HIV-1 protein Rev. There is voluminous literature on this subject, which has also been reviewed extensively (e.g., Cullen and Malim 1991). However, Rev has been critical to our current mechanistic understanding of export and a few words of introduction are unavoidable. During the viral life cycle, Rev contributes to the switch from early to late gene expression. In the early phase, products from fully spliced RNAs, including Rev, are synthesized. HIV-1 splicing is inefficient, however, and unspliced as well as partially spliced transcripts accumulate within the nucleus. In the late phase, Rev function results in the appearance of these viral transcripts in the cytoplasm, allowing the production of the viral structural proteins Gag, Pol, and Env, as well as the packaging of genomic RNAs into viral particles (Feinberg et al. 1986; Sodroski et al. 1986). Reporter gene experiments in tissue culture cells showed that Rev functions to promote the expression of unspliced RNA (Malim et al. 1989a). They also identified a region of the env premRNA that is necessary for Rev function. Rev is an RNA-binding protein and directly recognizes this RNA motif, the RRE (Rev response element; Hadzopoulou-Cladaras et al. 1989; Malim et al. 1989). This interaction gives specificity to Rev and explains how it selects env pre-mRNA for export to the cytoplasm (Heaphy et al. 1990; Malim et al. 1990; Zapp and Green 1989). As Rev increases the expression of RRE-containing RNAs even in yeast (Stutz and Rosbash 1994), Rev function and the cellular proteins with which it interacts must be highly conserved.

The most straightforward explanation of Rev's function is to directly export pre-mRN A export, as first proposed some time ago (Felber et al. 1989; Malim and Cullen 1993). A second possibility is that Rev directly inhibits pre-mRNA splicing (Chang and Sharp 1989; Kjems et al. 1991). The positive effects on export would then be indirect; splicing inhibition would lead to an increase in pre-mRN A levels, which would then lead to an increase in export through the normal cellular RNA route. Although there is some evidence that Rev has negative effects on splicing (Kjems and Sharp 1993), the compelling nature of subsequent experiments argues that the Rev effect is predominantly to promote premRNA export. 
This export function requires Rev's second functional domain, which is carboxy-terminal to the region that interacts with RNA and which contains several critically spaced leucine residues. Early mutagenesis experiments, largely by Cullen and coworkers, showed that this effector domain or N ES was critical for Rev function (Malim et al. 1989a, 1991). Several papers then indicated that export was the dominant focus of this leucinerich domain. Lührmann and colleagues showed that Rev was able to promote nuclear export of RRE-containing RN As in Xenopus oocytes independent of the presence of introns, indicating that splicing was probably unnecessary for Rev function (Fischer et al. 1994). Export was also indicated by yeast two-hybrid experiments, which identified novel yeast and mammalian nucleoporins (or nucleoporin-like proteins) as candidate Rev NES-interacting proteins with functional effects on Rev-mediated export. These proteins, including the yeast protein Riplp/N up42p, were proposed to be export receptors within the nucl eus or docking sites on the nuclear side of the pore (Bogerd et al. 1995; Fritz et al. 1995; Stutz et al. 1995).

A contemporary study showed that a peptide comprising the Rev NES could specifically inhibit Rev-mediated export. As this paper showed that bovine serum al bumin (BSA) coupled to the Rev peptide (BSA-R) was exported from the nucleus in mammalian cells as well as in oocytes, RNA export could be viewed as a protein export process with associated RN A cargo (Fischer et al. 1995). This shift in perspective was reinforced by a study showing that a cellular factor, the protein kinase $A$ inhibitor PKI, contains a functional Rev-like NES (Wen et al. 1995). There was al so evidence for a connection between Rev-mediated export and cellular RN A export. U snRN A and 5S RN A export, but not other RN A export pathways, was inhibited by injection of BSA-R into oocytes; no inhibition was observed with BSA-M , which contained the export-deficient M 10 mutant NES (M al im et al. 1989a). This finding established a tight connection between the protein export pathway mediated by Rev and this particular cellular RN A export pathway (Fischer et al. 1995). It suggested further that the latter uses one or more Revlike NES-containing proteins as RNA transporters and that the Rev and $U$ snRN A pathways share one or more dedicated components.

Searching for these components proceeded along several seemingly logical fronts. A yeast system was established with the hope of applying genetic tools and identifying candidate Rev-interacting proteins. Although the Rev effect in yeast is sufficient for analytical purposes, unfortunately it is not strong enough to be used in genetic screens (Stutz et al. 1995). The Rev-like NES also proved to be an enigmatic sequence motif. Other than several leucines or hydrophobic residues arranged with characteristic spacing, there are few diagnostic features (Bogerd et al . 1996). This made it difficult to identify cellular NESs with search paradigms and probably indicates that its unique structural features (at least in the absence of other proteins) are quite subtle. Although several candidate Rev-binding proteins have been identified biochemically, none has been convincingly implicated in Rev-mediated transport (Ruhl et al. 1993; Bevec et al . 1996; Schatz et al . 1998). There is reason to believe that the nucleoporin-like proteins identified by the yeast two-hybrid approach are more cre dible interactors, probably because this in vivo assay allows for a contribution by additional relevant yeast proteins to the two-component bait and prey complex (see below).

\section{The importin- $\beta$ family of transport receptors}

The third intersecting area is that of nuclear import re ceptors and their relatives, the importin- $\beta$ family. Indeed, the basic framework for thinking about RN A and protein export comes from the protein import field. Although there is still considerable mystery surrounding the nuclear pore itself and how import substrates traverse this large and complex organelle, during the past few years there has been startling progress in our understanding of the 'soluble phases' of the protein import process (Mattaj and Englmeier 1998). These are concerned with the events that occur in the cytoplasm prior to import and in the nucleopl asm subsequent to import. In the cytoplasm, a transport complex is assembled, which then docks at the pore. After traversing the pore and arriving within the nucleus, the transport complex is di sassembled, the cargo liberated, and the transport factors recycled back to the cytoplasm (for review, see Görlich and Mattaj 1996a; Görlich 1997; Nigg 1997).

Progress in understanding this soluble phase is due in part to a convergence of protein biochemistry and yeast genetics and has led to a near universal acceptance of the starting point: the cytoplasmic association of cargo with an import receptor. Different import substrates use different receptors, which are all members of the importin- $\beta$ family-also called karyopherin- $\beta$ (Fornerod et al. 1997b; Görlich et al. 1997; for review, see Görlich 1997, 1998; Weis 1998; Wozniak et al. 1998). In the best-studied case, nuclear localization signal (NLS)-containing substrates interact indirectly with importin- $\beta$ by binding directly to the importin- $\alpha$ subunit (Adam and Gerace 1991; Görlich et al. 1994, 1995b; Imamoto et al. 1995; Weis et al. 1995). Other import substrates have different signals and bind directly to other importin- $\beta$ family members. $\mathrm{N}$ ot all of these importins are essential in yeast, implying a certain level of functional redundancy (for review, see Pemberton et al. 1998; Weis 1998; Wozniak et al. 1998). There are al so important cofactors that assemble in a stable manner with substrate and receptor. These include the small GTPase Ran/TC4 (Gsp1p and Gsp2p in yeast; for review, see Koepp and Silver 1996; Corbett and Silver 1997; Görlich 1997; Cole and Hammell 1998; Dahlberg and Lund 1998; Izaurralde and Adam 1998). Ran may contribute to the docking of the N LS-receptor complex at the cytoplasmic face of the pore, which probably occurs through a direct interaction between the receptor and FXFG and GLFG repeat se- 
quence-contai ning nucleoporins (Adam and Adam 1994; Görlich et al. 1995a; lovine et al. 1995; Kraemer et al. 1995; Moroianu et al. 1995; Radu et al. 1995b; Rexach and Blobel 1995). Ran-dependent GTP hydrolysis also provides energy for the translocation through the pore, and Ran is required for the dissociation of the substratereceptor complex on the nucl ear side of the pore (Görlich et al. 1996).

The fact that Ran contributes to complex dissociation in the nucleus but allows complex formation in the cytoplasm is superficially enigmatic but fits well with other aspects of Ran's life style. Ran is inferred to be largely complexed with GDP in the cytoplasm and largely complexed with GTP in the nucleus. This presumed gradient reflects the fact that the Ran GTPase activating protein RanGAP1 (Rnalp in yeast) is primarily cytoplasmic (Hopper et al. 1990), and the Ran guanine nucleotide exchange factor RCC 1 (Prp20p in yeast) is primarily nuclear (Ohtsubo et al. 1989). RanGAP1 increases the intrinsic GTPase activity of Ran by up to five orders of magnitude and stimulates the conversion of Ran-GTP into Ran-GDP. The activity of Ran-GAP1 is itself stimulated 10-fold by the mainly cytoplasmic Ran binding protein RanBP1 (Yrblp in yeast; Bischoff et al. 1995; Schlenstedt et al. 1995; Richards et al. 1996). It makes sense, therefore, that import substrate-receptor complex formation occurs in the presence of Ran-GDP but is inhibited by Ran-GTP (Rexach and Blobel 1995; Görlich et al. 1996; Chi et al. 1997). A pparently, the reverse is true for export substrate-receptor complex formation: Ran-GTP is important if not essential for the formation of these complexes (A rts et al. 1998; Fornerod et al. 1997a; Izaurral de et al. 1997b; Kutay et al. 1997, 1998; for review, see Cole and Hammell 1998; Dahlberg and Lund 1998; Izaurral de and A dam 1998; see below).

In addition to the importin- $\beta$ family members known to function in protein import, several other importin- $\beta$-like proteins were identified by database homology searches (Fornerod et al. 1997b; Görlich et al. 1997; U II man et al. 1997; for review, see Pemberton et al . 1998). These were proposed to be novel transport factors based on two arguments. First, their conservation is highest at the amino terminus, where importin- $\beta$ is known to interact with Ran (Görlich et al. 1996, 1997; Chi et al. 1997; Fornerod et al. 1997b). Second, one of the family members with no known function, human CRM 1 (chromosome region maintenance 1), interacted directly with the nucleoporin CAN / N up214 (Fornerod et al. 1997b). This resembled the direct interaction of importin- $\beta$ to repeat-containing nucleoporins described above.

\section{CRM1, the export receptor for Rev}

Unexpectedly, the cytotoxin leptomycin B was the fourth intersecting area and provided a key experimental tool to identify the direct receptor for Rev-mediated export. Leptomycin B had been previously shown to kill Schizosaccharomyces pombe and its apparent molecular target was the product of the gene CRM 1; Ieptomycin B-resistant mutants of S. pombe map within the CRM 1 gene (N ishi et al. 1994). Importantly, leptomycin B was then shown to block both Rev export and Rev-dependent RNA export in mammalian cells (Wolff et al. 1997). Given that CRM 1 is an importin- $\beta$ family member (Fornerod et al. 1997b; Görlich et al. 1997), these data led to the exciting possibility that it might be the Rev NES receptor (Fig. 1).

Indeed, biochemical experiments in the M attaj Iaboratory showed that overexpression of CRM 1 in Xenopus oocytes stimulates both Rev and U snRNA export. Conversely, leptomycin B inhibits these two pathways, and this inhibition can be overcome by coinjection of excess CRM 1. In vitro, CRM 1 forms a complex with Ran-GTP and NES sequences from either Rev or PKI and the association is cooperative; in addition, leptomycin B inhibits complex formation, as the in vivo data predict (Fornerod et al. 1997a). The fact that Ran-GTP is requi red for the Rev-CRM 1 interaction explains the earlier lack of success in the biochemical isolation of bona fide Revinteracting proteins. Two other groups also identified a direct interaction between CRM 1 and cellular proteins with a Rev-like NES, but with no apparent requirement for Ran-GTP (Fukuda et al. 1997; Ossareh-N azari et al. 1997). Taken together, all the results indicate that the importin- $\beta$ family member CRM 1 is the Rev N ES export receptor. The cooperative nature of the tripartite interaction probably explains why biochemical fishing experiments with NES have been so unsuccessful: The absence of high levels of Ran-GTP in total extracts precludes a strong interaction between Rev NES and export receptors. The yeast two-hybrid experiments, on the

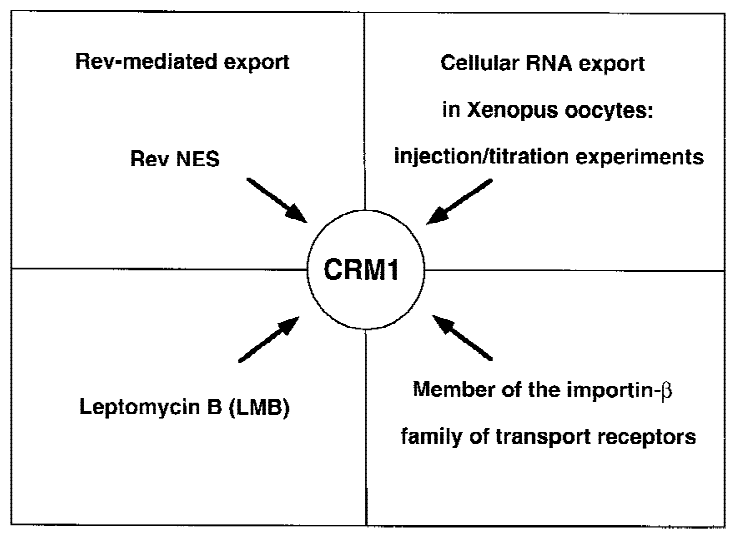

Figure 1. CRM 1 is the export factor for Rev-like NES containing substrates. Independent observations converged at the identification of CRM 1. S. pombe strains resistant to the cytotoxin leptomycin B had been mapped to the CRM1 gene. Xenopus oocyte injections showed that Rev uses a cellular export pathway dedicated to $U$ SnRNAs and 5S RNA; this pathway is inhibited by leptomycin B. CRM 1 was identified in a complex with the FG-nucleoporin CAN/N up214 and shown to be a member of the family of transport factors rel ated to importin- $\beta$. Rev NES directly interacts with CRM 1 and this interaction is sensitive to leptomycin $B$ (see text for references). 
contrary, benefitted from the high levels of Ran-GTP present within yeast nuclei.

Two other papers addressed the rol e of CRM 1 in yeast nuclei, that is, the role of the S. cerevisiae ortholog Crmlp. One created and utilized a sensitive N LS-GFPNES reporter protein (Stade et al. 1997). In wild-type cells, it is localized predominantly in the cytoplasm, indicating that NES activity dominates the phenotype. A temperature-sensitive (ts) CRM1 mutant (also called xpo1-1) led to rel ocal ization of the reporter protein to the nucleus. The inference is that the loss-of-function mutation decreased NES activity and therefore increased the ratio of N LS:NES activities. Crm1p was also shown to shuttle between the nucleus and cytoplasm. Taken together with a two-hybrid interaction between the Rev N ES and Crmlp, the data were consistent with the notion that Crmlp is the Rev N ES export receptor in yeast (Stade et al . 1997). The second utilized three viable lossof-function mutations in CRM1 (Neville et al. 1997). These mutations were originally identified based on their effects on localization of the yeast transcription factor Yaplp. Yaplp has a Rev-like N ES and its nuclear export is regulated (C. Yan. L.H. Lee, L.I. Davis, in prep.). All three mutations led to a significant decrease in Rev N ES-mediated RN A export. Taken together with a N ESCrmlp two-hybrid interaction as well as a strong interaction between Crm1p and Riplp/N up42p, these results also suggested that Crmlp was the export factor for the Rev NES. The three mutations also affected the twohybrid interaction between a NES and Riplp/N up42p (N eville et al. 1997). As this is the interaction that originally identified the candidate nucleoporin Riplp (Stutz et al. 1995), it suggests that NES-nucleoporin interactions might be indirect and mediated by Crm1p. This is precisely the role one imagines for an export receptor, namely, delivery of the export cargo to the nuclear pore. Consequently, the data from Xenopus oocytes, mammalian cells, and S. cerevisiae lead to a strong conclusion: Crmlp is the export receptor for Rev NES-containing proteins.

\section{Export receptors for tRNA and importin- $\alpha$}

Two other importin- $\beta$ family members have also been assi gned roles in export. The protein CAS is the exporter for the importin- $\alpha$ subunit. Similar to the requirements for complex formation between CRM 1 and its substrate Rev NES, an in vitro interaction between CAS and importin- $\alpha$ requi res Ran-GTP. CAS shuttles and binds preferentially to NLS-free importin- $\alpha$, which might aid in nuclear dissociation of importin- $\alpha$ from its substrates and also presumably decreases the capacity of importin- $\alpha$ to reexport import substrates (Kutay et al. 1997).

The third importin- $\beta$ family member involved in export is called exportin-t because it exports tRN A from the nucleus. In contrast to the earlier comment about RNA export being a protein export problem, this member of the importin- $\beta$ family binds and exports RNA rather than protein. Like the two other exportins, expor- tin-t shuttles and binds its substrate well only in the presence of Ran-GTP (Arts et al. 1998; Kutay et al. 1998). Indeed, the data support a cooperative interaction between exportin-t, Ran-GTP, and tRN A substrate. In permeabilized mammalian cells, addition of Ran-GTP causes a relocalization of recombinant exportin-t from the nucleoplasm to nuclear pores, consistent with the binding of exportin-t complexes to pores. Injection experiments in the oocyte system showed that exportin-t stimulates the rate or levels of tRNA export and overcomes the saturating effect of additional tRNA. The nature of the tRNA-exportin-t interaction will be interesting because the protein has no known RNA binding motif and because there is evidence that TRN A modifications as well as a mature 3'CCA end contribute to binding specificity (Arts et al. 1998; Kutay et al. 1998). A preference for processed tRNA is consistent with the lack of evidence for an exportin-t role in processing; perhaps exportin-t binds its substrate after most processing has taken place.

These results raise interesting questions when they are compared with data from $\mathrm{S}$. cerevisiae. Although only distantly related to exportin-t, the importin- $\beta$ family member Loslp appears to be the yeast ortholog, and recent in situ hybridization experiments indicate nuclear accumulation of tRN A in LOS1 loss-of-function mutants (Sarkar and Hopper 1998). Loslp has been known for almost 20 years to be important for yeast tRN A processing and the original los1-1 mutation causes inefficient tRN A splicing (Hopper et al. 1980; Hurt et al. 1987). Also, Loslp interacts with nuclear pore complexes, consistent with the general exportin picture (Simos et al. 1996). However, the gene is inessential, indicating that there must be an additional pathway for tRN A export. These genetic data are consistent with in situ hybridization data showing that the nuclear tRN A signal in LOS1 mutants is more modest than in some nucleoporin mutants, such as NU P116 temperature-sensitive mutants (Sarkar and Hopper 1998) or in Ran cycle mutants (H. Grosshans, E. Hurt, and G. Simos, unpubl.). In considering a relationship to processing, it is worth remembering that the tRNA splicing enzymes, endonuclease and ligase, are associated with the nuclear membrane (A bel son et al . 1998). As LOS1 is inessential, Loslp probably 'hel ps' deliver the pre-tRN A substrate to these activities, that is, to the nuclear membrane. But this more rel axed view is somewhat at odds with a stable nuclear exportin-substrate complex that persists until it reaches the cytoplasmic face of the pore. Perhaps the nuclear exportin-t complex is more dynamic in vivo and engages in multiple cycles of association and disassociation. Alternatively, pre-tRN A splicing might take place while the substrate is bound within the exportin-t complex.

\section{Does mRNA transport use an exportin?}

This question has two parts: Does mRNA transport use one of the three identified exportins, and is there more 
general evidence that mRN A transport uses exportins, perhaps another family member? With respect to the first part, there is no evidence that CAS or exportin-t is involved in mRN A export. But the connection between CRM 1 and mRNA transport is intriguing, especially in yeast.

In this system, a connection between Crm1p and mRN A transport has been made by the xpo1-1 mutant: After a shift to the nonpermissive temperature, mRN A export as well as Rev NES-mediated transport is rapidly and strongly inhibited (Stade et al. 1997). The simple interpretation is that Crmlp makes an important contribution to mRN A export. However, it is possible that the block to mRN A export is indirect, attributable to a more direct effect of the CRM 1 temperature sensitive mutation on another aspect of transport. The likelihood that this is protein import is somewhat reduced by the fact that these investigators examined this mode: It was affected much more slowly than mRN A export. But there are multiple protein import pathways, and the more general concern still remains: A block of one mode of transport (N ES-mediated protein export) might indirectly inhibit another (mRNA export). Consistent with the lack of a direct connection between these two modes is the viable nature of the three CRM 1 loss-of-function alleles. This suggests no more than a modest effect on mRNA export. Indeed, these viable alleles have no detectable impact on mRNA export as assayed by in situ hybridization, despite a potent effect on Rev-mediated RNA ( $\mathrm{Ne}$ ville et al . 1997) as well as protein export (M . N eville and M. Rosbash, unpubl.). In higher eukaryotes, the absence of a role for CRM 1 in mRN A export is al so supported by the following observations: As mentioned above, injection of Rev NES into oocytes competes with U SnRNA export but has no effect on mRNA export, suggesting that this pathway is distinct from the CRM 1-mediated pathway shared by Rev NES and U snRNAs (Fischer et al. 1995; Fornerod et al. 1997a). More importantly, leptomycin B does not inhibit mRN A export in oocytes and mammalian cells, whereas it strongly inhibits U snRN A export (Fornerod et al. 1997a; Wolff et al. 1997). In addition, overexpression in mammalian cells of a truncated, defective form of the nucleoporin CA N / N up214 that retains CRM 1 binding ability inhibits Rev-dependent gene expression but has no effect on the cellular mRNA export pathway (Bogerd et al. 1998). However, some of these results are controversial. A recent contribution suggests that oocyte injection of higher N ES pepti de concentrations, conjugated with a different carrier protein, inhibits mRN A export. Because there is also an inhibitory effect with the M10 mutant peptide, previously shown to have no NES activity, it is possible that the effect is only marginally rel evant to NES-mediated export (Pasquinelli et al. 1997b). At this time, one must therefore remain skeptical but open to the possibility that Crmlp and Rev-like N ESs contribute to mRNA export.

Are there indications that $\mathrm{mRNA}$ export requires another exportin-like receptor? Oocyte injection experiments have shown that nuclear depletion of Ran-
GTP inhibits the export of a variety of substrates including Rev, $U$ snRNAs, and mRNAs (Izaurralde et al. 1997b). Injection of the GTP hydrolysis-resistant GTPase RanQ69L (in subinhibitory amounts) restores Rev and partial mRNA export but not U snRNA export, indicating different GTP hydrolysis requirements for the export of different classes of substrates. Also, different mRNAs show different behaviors with respect to this GTP-hydrolysis requirement. This might reflect the existence of different mRNA export pathways or the presence of distinct hnRN P proteins on different transcripts (Izaurralde et al. 1997b; Saavedra et al. 1997a). In any case, the strict Ran-GTP requirement observed for the export of most mRN As tested so far is consistent with a contribution of importin- $\beta$ like factor(s) to mRNA export.

\section{What substrates for Crmlp?}

If one assumes that Crmlp is not relevant to mRNA export, then one should look to other RNA pathways or to protein export for the source of Crmlp substrates. This also questions the nature and role of yeast NESs recognized by Crmlp. Presumably there are yeast proteins, like mammalian PKI, whose export is constitutive or regulated. One is the yeast protein $\mathrm{Y}$ aplp, which has a bona fide Rev-like NES and whose transport is regulated by Crmlp (C. Yan L.H. Lee, L.I. Davis, in prep.). The S. pombe homolog Paplp is similarly regulated by Crmlp (Toone et al. 1998). Although there are several additional published proteins with some of the expected properties, (the yeast proteins Glelp or M ex67p for example; see below), these are only candidates at present. This is due to the fact that Rev-like NES sequences are so easy to find and so difficult to define unambiguously by statistical methods. We also believe that NES-reporter gene assays are not without interpretation difficulties: A leucine-rich regi on might function in this context but not necessarily in its natural location. At a minimum, extensive mutagenesis of a putative NES, preferably in its natural location as first done by Cullen and colleagues on Rev (M al im et al. 1989a, 1991), is necessary to demonstrate convincingly Rev-like NES function. N ote that this type of analysis on the Rev NES in yeast indicates that the Rev NES-Crmlp interaction (presumably Rev NES-Crm1p-Ran-GTP) closely resembles the Rev NES-CRM 1 interaction of mammals (Stutz et al. 1995, 1996).

The current absence of many bona fide Rev N ES-containing yeast proteins has an interesting and unexpected implication: Y east NESs may not resemble perfectly a canonical Rev NES. A substantial difference would lead not only to different NES mutagenesis results with a candidate yeast NES but would also help explain the phenotypes of the three viable loss-of-function CRM1 mutants. These mutants have strong effects on Rev but little or no effect on growth and mRNA export (N eville et al . 1997). Were the Rev NES to be an imperfect mimic of a natural yeast NES, the former would fit less well 
into the Crmlp NES-binding pocket and therefore be more sensitive to mild Crmlp loss-of-function mutations. A difference between the N ES-binding pockets of Crmlp and CRM 1 proteins from other species is also consistent with a significant difference in leptomycin B-sensitivity. The insensitivity of S. cerevisiae to this reagent is not due to permeability but to an actual physical difference between yeast Crmlp and S. pombe Crm1p (Fornerod et al. 1997a). Y east two-hybrid interactions between Rev NES and S. pombe Crm1p are leptomycin B-sensitive, whereas the comparable interaction with the S. cerevisiae protein is insensitive ( $M$. N eville and $M$. Rosbash, unpubl.). Consequently, one must remain open to the possibility of yeast substrates that differ from a canonical Rev or PKI NES as well as to different physi ol ogical roles of Crmlp-mediated export in this organism-including mRN A export.

The most likely role of CRM 1 in RN A export is still $U$ snRN A and 5S RN A export in vertebrate systems. As described above, this is because of the impressive inhibition of $U$ snRN A export by injection of excess Rev N ES peptide or leptomycin B into oocyte nuclei. Because injection of excess mono-methyl $G$ cap also inhibits these pathways, it was proposed that the cap connects to the export machinery that carries these RNAs out to the cytoplasm (Hamm and Mattaj 1990). This led to the purification and cloning of the nuclear cap-binding complex (CBC), CBP20 and CBP80. These proteins bind to the cap shortly after it is added to RN A on nascent transcription complexes and contribute to their nuclear export (Hamm and Mattaj 1990; Izaurralde et al. 1992, 1995). There is now evidence for an in vitro interaction between CBC and CRM 1 (I. M attaj, pers. comm.). If CBC physically and conceptually links U SnRN As to CRM 1, this provides, at least in principle, a complete picture of snRN A transport from nascent transcription to the pore. Presently, it is unclear whether this description also applies to yeast $U$ snRNAs and Crmlp. As mentioned above, it has not been shown that yeast $U$ snRNAs are exported and reimported into nuclei as in vertebrate systems. It is possible that yeast snRN Ps never leave the nucleus, which would indicate that the addition of Sm proteins, snRNP assembly, and cap trimethylation are entirely nuclear processes in this organism.

A role for CBC and possibly CRM 1 in snRNA export thus raises the question of why the data so clearly show that this interaction is not essential for mRN P transport in vertebrates (Fornerod et al. 1997a; Izaurralde et al. 1995). This is despite the fact that RNA polymerase II pre-mRNA transcripts are capped and decorated by CBC indistinguishably from newly synthesized snRN A transcripts (Visa et al. 1996b). We can imagine two possibilities. First, the interaction between CBC and CRM 1 may not occur or may be al tered in nuclear $\mathrm{MRNP}$ relative to snRN P. For example, the presence of an adjacent hnRN P protein in $\mathrm{mRN} P$ could influence $C B C$ and affect its interaction with CRM 1. Second, mRN A could be intrinsically 'more difficult' to transport than a small structured RN A. The same cap-CBC-CRM 1 complex might be sufficient or play a major role in the case of the latter but not the former. This offers an attractive explanation for the mRN A export block in theyeast CRM 1 temperaturesensitive mutant: (1) Crmlp binds to CBC and is a component of nuclear RN P, (2) this Crmlp activity aids but is insufficient al one for mRN P export, and (3) at the nonpermissive temperature, the mutant Crmlp has a negative effect on the mRN Ps to which it is bound. A nother explanation is that Crmlp is involved in the reexport of factors that can inhibit mRN A export. Crmlp-mediated export may normally prevent their nuclear accumulation.

\section{Nuclear retention vs. nuclear export}

Some of the above considerations suggest that successful export must be sufficiently robust to overcome RN A or RN P retention within the nucleus. As export is a selective process, failure may not only reflect the absence of a strong export signal but also the presence of a strong nuclear retention signal. Indeed, there are clear circumstances where these two processes (RNA export and RNA retention) are in competition.

This principle has been articulated in detail within the context of Rev-mediated pre-mRNA transport. In this system, spliceosome assembly inhibits premRNA export presumably because one or more spl iceosome components block transport. The block might reflect an intrinsic feature of mature snRN Ps, which are restricted to nuclei. In this view, a simple Rev transport function is not an entirely satisfactory explanation. How does Rev overcome spliceosome-mediated retention? Consistent with a role of Rev in spliceosome disassembly is a result from the yeast system: The introduction of a branchpoint mutation into a Rev-responsive reporter premRNA prevents Rev-dependent pre-mRNA export; the mutation, which blocks the first step of splicing, is epistatic to Rev's positive effect on pre-mRN A cytoplasmic Iocalization (Stutz and Rosbash 1994). We suggest that Rev influences features of splicing, at least retention features, in addition to its effects on transport. An inference is that antiretention features, such as spliceosome disassembly factors, are concentrated at or near nuclear pores-analogous to the nucl ear membrane local ization of tRN A splicing factors. In this scenario, the Rev export receptor would aid in spliceosome disassembly by bringing substrates to the pores. This would serve to increase the local concentration of the relevant factors and inhibit retention. Although the branchpoint mutant would be expected to lower the efficiency of spliceosome assembly, it is conceivable that it has an even more deleterious effect on pre-mRNA spliceosome disassembly. The Rev-mediated increase in local enzyme concentration would be insufficient to disassemble the mutant spliceosomes.

An alternative, not necessarily incompatible, view relies on the propensity of Rev to polymerize along an RNA transcript. For example, the complete viral RRE element is known to favor the binding of multiple Rev molecules (Heaphy et al. 1991; Zapp et al. 1991). This 
might serve two protransport functions: It would increase the number of bound CRM 1 molecules and presumably CRM 1 export activity, and it might inhibit retention by competing with and displacing spliceosome components or other retention elements. CRM 1 could even aid in Rev polymerization (Hakata et al. 1998).

If CRM 1 does not contribute directly to cellular mRN P export, other positive transport factors must exist. Some of these may even be deposited on the RNA substrate during splicing. This notion is contrary to the spliceosome-retention view articulated above and is based on the observation that some genes, $\beta$-globin, for example, are poorly expressed as CDN As (Buchman and Berg 1988). Also relevant is the fact that some naturally intronless transcripts, like those from the HSV (herpes simplex virus) thymidine kinase gene, contain an RNA element necessary for transport (Liu and Mertz 1995). Similarly, the intronless mouse histone $\mathrm{H} 2 \mathrm{a}$ transcript contains a small el ement that facilitates cytoplasmic accumulation (Huang and Carmichael 1997).

\section{Role of hnRNP proteins in mRNA export}

In thinking about nuclear RNP, the current prevailing notion is that many associated RNA binding proteins, so-called hnRN P proteins, facilitate and are perhaps essential for the export of the RNAs to which they are attached (for review, see Nakielny and Dreyfuss 1997; $\mathrm{N}$ akiel ny et al. 1997). This connection between hnRN P proteins and export is due predominantly to the pioneering experiments of Dreyfuss and colleagues. They showed that many of these proteins are not limited to the nucleus as had been previously believed, but shuttle continuously between nucleus and cytoplasm. Export does not require RN A synthesis, suggesting that the active process is hnRNP or protein export and that the RNA transcripts are passive cargo-analogous to Revmediated export (Piñol-Roma and Dreyfuss 1992). Subsequent work has defined a specific export signal on hnRNP A1, called M9, which is distinct from Rev-like N ESs (Michael et al. 1995). Therefore, at least some family members are like Rev and have at least two essential domains: an RNA binding region and an effector region that somehow connects to nucl ear export. There is even evidence that different shuttling hnRN P proteins have different export signals, which use nonidentical export pathways (Michael et al. 1997). As different primary transcripts are decorated by different sets of hnRN P proteins (Matunis et al. 1993), these may define the nonidentical export pathways used by different mRNAs in the oocyte system (Izaurral de et al. 1997a,b; Pasquinelli et al. 1997a; Saavedra et al. 1997a). The critical role of RNP proteins in RNA export may be equally applicable to ribosome export, in which a specific RNA-binding protein could be the direct export substrate with the RNA coming al ong for the ride. But it is important to note that, with the exception of the above discussion about Crm1p, no mRNA-relevant export receptors are known. The M9 sequence in hnRNP Al signals both import and export (Michael et al. 1995), and hnRN P A 1 is imported through an interaction with the import re ceptor transportin (Pollard et al. 1996). Although an import receptor could serve as an export receptor, transportin is unlikely to be involved in hnRN P Al export (Izaurralde et al. 1997a; Siomi et al. 1997). The relevant export receptor remains unknown (Fig. 2).

Analogous to Rev and splicing, the hnRNP literature al so suggests that there is a struggle between RN A-binding proteins that are retained and RN A-binding proteins that are export substrates (for review, see $\mathrm{N}$ akielny et al. 1997). Therefore, nuclear mRN Ps might be more difficult export substrates than snRN As, because some of the bound proteins might promote retention rather than export. In contrast to hnRN P A 1, hnRN P C is not exported and does not shuttle. This is probably not just attributable to the absence of an export signal, because a chimeric protein between hnRN P C and the transport competent region of hnRNP Al fails to shuttle, that is, hnRN P C wins (N akiel ny and Dreyfuss 1996; Nakielny et al. 1997). This indicates that some hnRN P retention is active and suggests that bound hnRNP C may impede export of an RNA, or that hnRNP C removal may be a prerequisite for cytoplasmic transport. Consistent with the latter possibility, microscopy experiments in the

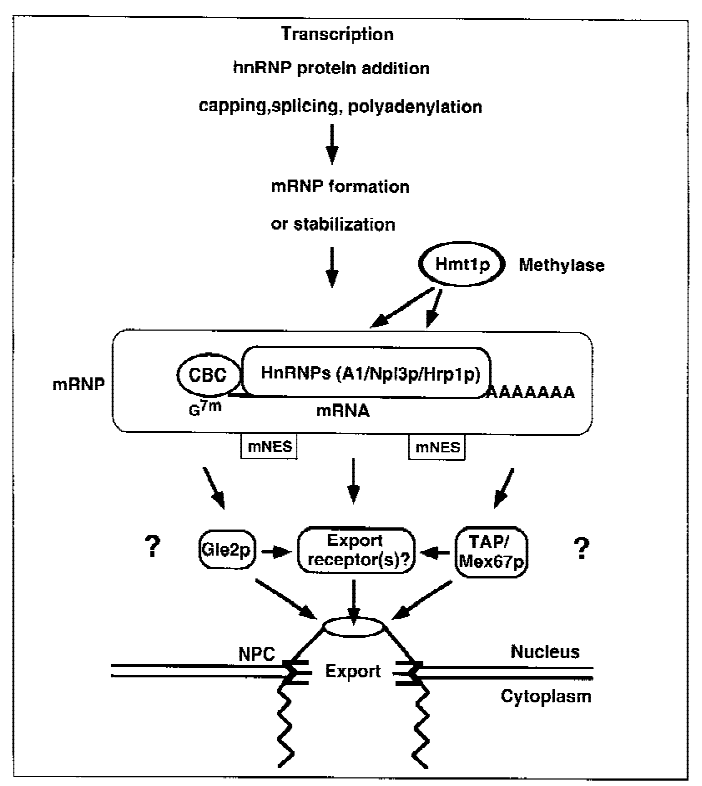

Figure 2. Following transcription, the pre-mRNA is processed and packaged into a mature RN P competent for nucl ear export. In yeast, the methylase $\mathrm{Hmtlp}$ may participate in the formation and stabilization of the mRN P or the release of the MRN P from the nucleus. With the exception of the hnRN P A 1 M 9 sequence, the mRN P nuclear export signal (s) (mNES) have not been identified and it is not clear whether an importin- $\beta$ like receptor is involved in mRNA export. Factors such as Gle2p and TAP1/ Mex67p could mediate mRNA export by bridging the mRNPexport receptor interaction or more directly the mRN P-nuclear pore complex interaction. (N PC) N uclear pore complex (see text for references). 
Chironomous balbiani ring system indicate that the insect version of hnRN P C is stripped from the RNP at or near the pore just prior to export. In contrast, the insect version of hnRNP A 1 remains part of the RNP during export through the pore (Alzhanova-Ericsson et al . 1996; Visa et al. 1996a). The importance of hnRN P C removal from the RN P transcript at the pore might be analogous to the more speculative notions about spliceosome disassembly articulated above. Moreover, there are enzymatic activities at or near the pore that might contribute to RNP remodeling as well as to RNP export (SnayHodge et al. 1998; Tseng et al. 1998).

\section{hnRNP proteins and mRNA export in yeast}

All of these considerations reinforce the notion that the nuclear mRNA export substrate is an RNP complex rather than RN A. From a yeast genetic point of view, an RN P network and its rel ationship to export has been best explored by Silver and colleagues (Henry et al. 1996; Kessler et al. 1997; Shen et al. 1998). This story begins with the yeast hnRN P protein N pl3p. The protein was originally implicated in a number of processes, including RNA export, protein import, and rRNA processing (Bossie et al . 1992; Russell and Tollervey 1992; Singleton et al. 1995). It is predominantly a nuclear protein, resembles by sequence the vertebrate RN A-binding protein hnRNP A1 and has been shown to cross-link to poly(A) ${ }^{+}$RNA (Flach et al. 1994; Wilson et al. 1994). It is therefore reasonable to consider it a yeast hnRN P protein. But its RNA-binding RRM domain contains a signature motif typical of the RNA recognition motif (RRM ) region of the SR (serine-arginine-rich) family of splicing cofactors (Birney et al. 1993); however, N pl3p presents no obvious SR domain. As there are no bona fide yeast SR proteins, N pl3p might be a bifunctional protein with the functions of the hnRNP Al family as well the SR splicing family.

Because $\mathrm{N}$ pl3p shuttles between the nucleus and cytoplasm and the export of poly $(A)^{+}$RN A is blocked in a temperature-sensitive mutant of NPL3 (Lee et al. 1996), it has been proposed that N pl3p is an RN A export factor, anal ogous to Rev or to hnRN P A 1. But unlike these two

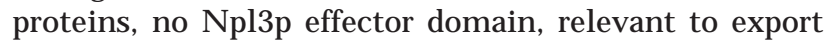
and separate from the RNA-binding regions, has been identified. Moreover, and also unlike hnRN P A 1, N pl 3p export is dependent upon ongoing RNA polymerase II transcription (Flach et al. 1994; Lee et al. 1996). This is similar to SR protein shuttling, which requires RNA binding. Moreover, the SR domain does not confer export function on its own (Caceres et al. 1998). Therefore $\mathrm{Npl3p}$ could be passive cargo and the RNA (or some other component of the RNP) more directly relevant to export. In this case, the effect of $\mathrm{N} \mathrm{pl3p}$ temperature-sensitive mutants on poly $(A)^{+}$RN A export would be due to mutant effects on the RNP transport substrate. These could cause poor RN P formation, unstable RN P, or otherwise al tered nuclear RN P. The mutant proteins could also affect RN P by causing aberrant protein-protein in- teractions and poisoning other hnRN P or nuclear protein activities. In this case, the temperature-sensitive mutants are more likely to manifest dominant effects, which have not been examined carefully (P. Silver, pers. comm.).

An effect on RN P assembly is well supported by the elegant genetics that Silver and colleagues have done. Through a combination of approaches, they have expl ored the genetic space around NPL3 and have come up with a number of genes, all of which can be interpreted to affect nuclear RNP in interesting ways (Fig. 2). The hnRNP protein Hrplp was identified in a selection for suppressors of a temperature-sensitive mutant of NPL3. This nuclear RNA-binding protein was subsequently assigned a precise role in $3^{\prime}$ end formation (Henry et al. 1996; Kessler et al. 1997). It recalls the earlier experiments of Birnstiel and colleagues that indicated an important role for 3 '-end formation in the export of the nonpolyadenylated histone mRNAs: Histone mRNAs were efficiently exported when produced by the normal 3 '-end cleavage pathway but not when produced by ribozyme cleavage; these data suggested that factors involved in histone RNA 3 '-end formation were required for export (Eckner et al . 1991). It al so recalls the fact that the $3^{\prime}$ as well as the 5'ends of RN A/RN P appear to make direct contact with nuclear pores prior to export (M ehlin et al. 1992; Kiseleva et al. 1996; for review, see Daneholt 1997).

The protein Hmtlp was i dentified in a synthetic lethal screen for N PL3-interacting genes. It is the major hnRN P methylase and has been shown to methylate both N pl 3p and Hrplp (Henry and Silver 1996; Shen et al. 1998). HMT1 is inessential. Although the data do not exclude another more minor methylase, they suggest that hnRNP methylation is largely inessential. The fact that HMT1 overexpression can suppress the temperature-sensitive growth of certain NPL3 mutant al leles suggests a relationship between the NPL3 mutant phenotype and the function of hnRN P methylation. As the direct cause of the temperature-sensitive growth of NPL3 mutants as well as the function of hnRN P methylation is unknown, these results are somewhat difficult to interpret. But a simple idea is that methylation serves to weaken hnRN P RNA binding. The RGG regions of hnRN P proteins, the principal sites of hnRNP methylation (Liu and Dreyfuss 1995), might bind directly to RNA and too tightly in the absence of methylation. Perhaps nuclear RNA binding proteins, even the ones that transit the nuclear pore along with the RN A, need to maintain some conformational flexibility to allow optimal RNA export; the absence of methylation may reduce the efficiency of such rearrangements. If the temperature-sensitive mutant protein fails to adopt a proper conformation and inappropriately acts as a retention signal, this can perhaps be overcome by further weakening the protein's RN A binding with excess Hmtlp activity. According to this scenario, the mutant protein can poison the transport of an mRN A to which it is attached, despite the fact that the wild-type protein has no active or direct role in $\mathrm{mRNA}$ export.

An additional genetic step was taken when a synthetic 
lethal screen starting with a deletion of HMT1 came up with the large subunit of the CBC, CBP80 (Fig. 2). Cbp80p is also inessential, and the double deletion of CBP80 and HMT1 is lethal as expected (Shen et al. 1998). Presumably, some feature of nuclear RN P, assembly or stability perhaps, is impacted by the double absence of CBC and hnRNP methylation. Npl3p shuttling is decreased in the absence of HMT1, but there is no effect of the deletion on poly $(A)^{+}$RN A localization (Shen et al. 1998), suggesting that $\mathrm{N} \mathrm{pl3p}$ export can be dissociated from bulk mRNA export. Unlike Npl3p, however, Cbp80p continues to shuttle in the absence of HMT1. As vertebrate experiments have linked CBC to CRM 1, it is possible that this link al so exists in yeast and is relevant to yeast messenger RN P as well as snRN A export. But at the moment one can only speculate about links from nuclear RNP to export receptors. Candidates include CBC, N pl3p, Hrplp and Crmlp, but they remain candidates.

\section{Nuclear pore complex structure and function}

To understand fully nucleocytoplasmic transport, it is important to identify the numerous components of the nuclear pore complex (N PC) and to assign them a function. The biochemical and genetic dissection of this macromolecular complex has led to the isolation of a substantial fraction of its components, also called nucleoporins or NUPs (Fabre and Hurt 1997). The overall structure/organization of the NPC is evolutionary conserved and the recent identification of many of its constituents reveals a reasonable conservation between yeast and higher eukaryotes, consistent with the homology observed among the soluble components of the transport machinery. Biochemical purification of nucleoporins has been the main approach in Xenopus or mammalian systems; in yeast, biochemistry has been complemented effectively by genetic approaches: experimental genetics as well as completion of the yeast genome project. As a consequence, of the 50 proteins identified in highly purified yeast pore preparations (Rout and Blobel 1993), >30 have now been cloned. Investigations into their function continues. Interestingly, many of these pore proteins are inessential for growth suggesting functional overlaps between various pore components; alternatively, inessential factors may be required to optimize or specialize pore function (for review, see Pante and Aebi 1996a; Doye and Hurt 1997; Fabre and Hurt 1997).

A mong the genetic approaches used in yeast to identify new pore components, the synthetic lethal approach has proven to be particularly rewarding (Doye and Hurt 1995). Such screens take advantage of the fact that a conditional mutant in a pore component is viable on its own, but is lethal in combination with a second mutation, presumably in a functionally related gene. Two components may be synthetically lethal because they are in the same complex, perform similar functions, or because they participate in the same pathway.
Initial screens of this type were carried out with mutants of the two first cloned pore genes, NSP1 and NUP1 (Wimmer et al. 1992; Belanger et al. 1994), which then led to the identification of a whole series of new pore complex proteins. These then served as starting points for subsequent synthetic lethal screens and identified a complex network of genetic interactions among numerous NPC components. Some of these genetic interactions were subsequently shown to reflect physical interactions. For example, NSP1 mutants undergo synthetic lethal interactions with NUP49, NIC96, and NUP57 mutants (among other nuclear pore genes), and N splp, N up49p, Nic96p, and Nup57p have been shown to be part of a nuclear pore subcomplex (Grandi et al. 1993). Based on partial sequence conservation, a homologous complex was described in higher eucaryotes and consists of mammalian p62, N up54, N up58, and N up93 (Guan et al. 1995). Another yeast subcomplex was identified by affinity purification with protein A-tagged N up84p and consists of N up85p, N up120p, Sec13p, and Seh1p in addition to N up84p (Siniossoglou et al. 1996).

Synthetic lethal screens have more recently been expanded to the NPC genes NU P49, NUP100, RIP1, and NUP85, all of which identified new as well as already known pore or pore-associated proteins, suggesting that the identification of nucleoporins in yeast is coming close to an end (for review, see Doye and Hurt 1997; Fabre and Hurt 1997). The fact that most of these screens identified proteins restricted to the N PC underscores the power of this genetic approach to identify components of a macromolecular complex. The same observation has been made for spliceosome components (Stutz et al. 1998), and appears to be true for nuclear mRNP (see above comments on RNP).

A useful complementary approach is the analysis of conditional mutants by in situ hybridization with oligo(dT) probes. This searches for mutants that cause nuclear accumulation of poly $(\mathrm{A})^{+} \mathrm{RN} A$ under restrictive conditions. A number of these RAT (mRN $\underline{A}$ trafficking) or MTR (mRN A transport) mutants turned out to be pore mutants (A mberg et al. 1992; Kadowaki et al. 1992).

NUPs identified in yeast or in higher eukaryotes can be grouped loosel y based on their molecular composition and/or location within the pore. The first class consists of integral membrane proteins (yeast Pom152 and mammalian gp210 and POM 121), which are believed to make up the core of the N PC and to anchor the complex into the nuclear membrane. The second class, comprised of 10 members in yeast, consists of the phenylalanine-glycine or FG-repeat-containing NUPs. These pore components are thought to be located at the N PC periphery (mainly based on immunoelectron microscopy studies in higher eukaryotes) and are characterized by domains rich in FG, GLFG, or FXFG repeats. These sequences are not NPC targeting signals and are in most cases dispensable for growth, suggesting functional redundancy among different FG-repeat domains. The in vivo function of these regions is not known, but they have been shown to interact with soluble transport factors in vitro, in Xenopus extracts and in vivo (Belanger et al. 1994; Radu et al. 
1995a; Rexach and Blobel 1995; Fornerod et al. 1997b; Shah et al. 1998). M any other pore proteins do not contain FG repeats but contain other motifs: These include coiled-coil domains, heptad repeats, zinc fingers, leucine zippers, and some sequences consistent with RN A-binding domains (for review, see Rout and Wente 1994; Davis 1995; Pante and Aebi 1996b; Doye and Hurt 1997; Fabre and Hurt 1997).

Although yeast appears to be a system of choice for identifying N PC components, the next challenge is to assi gn specific functions to each protein. Clues as to how nucleoporins function in vivo can be obtained from phenotypi c anal ysis of nucl eoporin mutants. These analyses include in vivo tests for defects in nuclear protein import, poly $(A)^{+}$RNA export and diffusion of proteins through the N PCs (Amberg et al. 1992; Kadowaki et al. 1992; Saavedra et al . 1996; Shulga et al . 1996). Functional analysis, however, is complicated by the fact that the role of many nucleoporins may be primarily structural with only a fraction playing a more specific role in transport. A nother problem comes from the fact that nuclear pores serve as the transit site for macromolecules both entering and exiting the nucleus. As described above, effects on import may also indirectly affect export. Despite these complications, a subset of nucleoporins has been assigned a primary role in RNA export. This is based largely on the fact that conditional mutants induce a rapid block in poly $(\mathrm{A})^{+} \mathrm{RN} \mathrm{A}$ export without a concommitant block in import. Such genes have been identified in the temperature-sensitive mutant screens for a specific block in poly $(\mathrm{A})^{+}$RNA export as well as in other more traditional genetic screens. They comprise NU P84, NU P85/RAT9, RAT2/NUP120, NUP159/RAT7, and RAT3/NU P133. N ote that these include three members of a nucl ear pore subcomplex menti oned above. It will be interesting to determine the location of this subcomplex within the pore, if it is associated with the nuclear baskets for example. It is al so of interest to define whether some of these pore components are present at more than one location, indicative perhaps of a more dynamic role during transport.

\section{NPC-associated components with a role in RNA export}

Several other pore or pore-associated proteins have more recently been proposed to have primary roles in RNA export. One is the nonessential protein Gle2p/N up40p that directly associates with the FG-nucleoporin Nup116p. GLE2 mutants are synthetic lethal with a NUP100 disruption (Murphy et al. 1996; Bailer et al. 1998). Gle2p and its S. pombe homolog, Raelp, are located at the pore with some fraction in the cytoplasm, and mutations in these factors induce a rapid block in mRN A export (Brown et al. 1995; Murphy et al. 1996; Bailer et al . 1998). The function of Gle2p is coupled to its interaction with a short region from $\mathrm{N}$ up116p that targets Gle2p to the pore. In the absence of this interaction, cells exhibit NPC herniations with a membrane seal over the pores typical of both NUP116 and GLE2 mu- tants; it is thought that these morpholigical perturbations are secondary to an RNA export defect because their appearance follows the nuclear accumulation of poly (A) ${ }^{+}$RNA (Wente and Blobel 1993; Murphy et al. 1996; Bailer et al. 1998). The N up116p sequence targeted by Gle2p is conserved in vertebrate nucl ear pore proteins related to N up116p, such as N up98, indicating that the docking of the Gle2p/Raelp protein family to nuclear pores might occur through a conserved mechanism (Bailer et al. 1998). Although a physical interaction between Gle2p/Raelp and RN A has not yet been demonstrated, a human homolog of Gle2p, M RN P41, was identified by cross-linking to poly $(A)^{+}$RN A. It is localized at the pore and in the cytoplasm, possibly in association with cytoskeletal elements. It was suggested that M RN P41 might partici pate in the cytopl asmic transport of mRNPs along cytoskeletal elements as well as in some feature of mRN P export (Kraemer and Bl obel 1997).

The synthetic lethal screen with a null allele of NU P100 al so identified Glelp as a candidate RN A export mediator (Murphy and Wente 1996). Glelp was cloned independently as a high-copy suppressor of a RAT7/NUP159 temperature-sensitive mutant (Del Priore et al. 1996), in synthetic lethal screens with Riplp (Stutz et al. 1997) and the N uplp (M. Kenna and L. Davis, unpubl.) pore proteins, as well as in a screen for coldsensitive mutants exhibiting splicing and poly $(\mathrm{A})^{+} \mathrm{RN} A$ export defects (Noble and Guthrie 1996). Consistent with these genetic interactions, Glelp localizes mainly to the NPC (Del Priore et al. 1996; M urphy and Wente 1996). Intriguingly, Glelp was shown to contain an essential Rev-likeN ES required for mRN A export (M urphy and Wente 1996). However, Glelp has not been shown to bind RN A nor to shuttle, and no connection has yet been established between GI elp and the N ES receptor C rmlp. This raises the question of whether the Glelp NES acts as a nuclear export signal in the context of the whole protein or whether this sequence plays another role in yeast mRN A export. Interestingly, a human homolog of Glelp, involved in mRNA export in mammalian cells, contains no N ES and is abl e to compl ement a yeast GLE1 temperature-sensitive mutant. Function in yeast however requires that a Rev-like NES be inserted into the region of the human protein that aligns with the NES from yGlelp (Watkins et al. 1998). This result underscores the functional importance of the yeast Rev-like NES region, but it does not clarify whether this N ES-like sequence is really a nuclear export signal or whether it is important for another aspect of Glelp function in yeast, such as localization through an association with other pore proteins.

A nother factor with a direct role in mRNA export, called Mex67p, was identified in a synthetic lethal screen with an amino-terminal deletion mutant of NU P85, which exhibits an RN A export defect (Segref et al. 1997). M ex67p mainly local izes at the pore and probably plays a direct role in mRNA export because temperature-sensitive alleles of MEX67 show a very rapid block in poly $(A)^{+}$RN A export with no apparent import block. Importantly, M ex67p cross-links to poly $(A)^{+}$RN A 
despite the absence of a previously identified RN A-binding domain. It is not clear whether M ex67p shuttles between nucleus and cytoplasm to perform its transport function or whether it remains at the pore. As mutant forms of Mex67p mislocalize to either the nucleus or cytoplasm, the association of M ex67p with the pore may be transient and dynamic. Mex67p also contains an essential carboxy-terminal Rev-like NES, and mutations therein interfere with the association of M ex67p and the nuclear pore and interfere with $\operatorname{poly}(A)^{+}$RNA export. However, it is not clear whether this sequence acts as a bona fi de N ES or whether its homology to Rev-like N ESs is fortuitous (Segref et al. 1997). In this context, TAP, the human homolog of Mex67p, contains no Rev-like NES (Grüter et al. 1998; Segref et al. 1997).

Human TAP was recently and independently identified as the cellular factor recruited by the CTE (constitutive transport element) of type $D$ retroviruses (Grüter et al. 1998). These simple retroviruses do not encode a Rev-like trans-acting protein but still must export unspliced and poorly spliced transcripts like complex retroviruses. This process relies on the interaction of a cisacting RNA element (the CTE) with cellular factors (Bray et al. 1994; T abernero et al. 1997). TAP was shown to directly bind to the CTE and to promote the export of CTE-containing transcripts in the Xenopus oocyte system (Grüter et al. 1998). Interestingly, injection of an excess of CTE RNA blocks mRNA export, indicating that TAP is also an essential mediator of cellular mRN A export (Pasquinelli et al. 1997a; Saavedra et al. 1997a). N oteworthy is the observation that an excess of hnRN P A 1, which saturates the export of specific mRN As, does not interfere with CTE-mediated export. This suggests that TAP promotes RN A export at a step following the interaction of certain mRNAs with hnRNP Al (Izaurralde et al. 1997a; Saavedra et al. 1997a; Grüter et al. 1998). These data al so indicate that the binding of TAP to the CTE is able to bypass certain steps in the mRN A export pathway and to override nuclear retention mechanisms. TAP has been purified from nuclear extracts, indicating that at least a fraction of this protein is soluble and supporting a transient association with the pore. It will be interesting to determine whether TAP interacts directly with messenger RNAs and whether it might have a regulatory role by targeting specific $\mathrm{mRNA}$ sequences for export.

A final interesting player in $\operatorname{poly}(A)^{+}$RNA export is the recently described DBP5/RAT8 gene, which encodes a member of the DEAD box family of RNA helicases. A temperature-sensitive al lele of RAT 8 was identified initially in the screen for poly $(A)^{+}$RN A retention mutants (RAT mutants) and concomitantly because of its similarity to other RNA helicases (Snay-Hodge et al. 1998; Tseng et al. 1998). RAT8 mutants show a much faster and stronger nuclear accumulation of $\operatorname{poly}(A)^{+} \mathrm{RN} A$ than the previously described heli case M tr4p, which has been suggested to play a role in mRNA export (Liang et al. 1996; Snay-Hodge et al. 1998). Dbp5p/Rat8p is found in the cytoplasm, but a substantial fraction is associated with NPCs. The link between Dbp5p/Rat8p and RNA export is strengthened by the absence of an import defect and by the identification of synthetic lethal interactions with the nucleoporins Rat7p/N up159p, Rat9p/N up85p, Rat10p/N up145p, and Riplp/N up42p, which have been independently implicated in export. There are also genetic interactions with the export/transport factors Glelp/Rsslp and Rnalp (Snay-Hodge et al. 1998). D bp5p/Rat8p has RNA-dependent ATPase activity and RNA helicase activity in vitro, but the latter requires an additional factor (T seng et al. 1998). Theidentification of this RN A-dependent ATPase is interesting because very few enzymes involved in RNA export are known. The presence of several potential NESs within Dbp5p/Rat8p raises the possibility that it shuttles and might accompany RNPs during the export process together with the targetting components. Its enzymatic activity might serve to induce required RN P rearrangements at the pore before export, or in the cytoplasm to allow recycling of shuttling RNA-binding proteins. All these unfolding or rearrangement processes may be energy dependent. The export of several substrates, including tRN A, NES-proteins, and importin- $\alpha$, have been shown to be dependent on Ran-GTP, but GTP hydrolysis was not required for export. These observations suggest that a different energy source, perhaps ATP hydrolysis, may be used for the export of certain substrates (Izaurral de et al. 1997b; Richards et al. 1997).

\section{Heat shock RNA export}

Heat or ethanol stress blocks normal poly(A $)^{+}$RNA export, but heat shock (HS) RNAs are exported efficiently under these conditions. This process is apparently independent of the Ran regenerating system (Saavedra et al. 1996): Mutations in the Ran-GAP Rnalp and in the nucleotide exchange factor RCC1/Prp20p, as well as high level expression of a dominant-negative Ran (Gsplp) mutant locked in its GTP-bound form, do not interfere with HS RNA export. One possibility is that another GTPase is involved in HS shock RN A export. Alternatively, HS RN A export may only require low levels of nuclear Ran-GTP, in which case the low residual amounts of nuclear Ran-GTP in the prp20-1 mutant would be sufficient. Also, the apparent absence of a requirement for the Ran-GAP (insensitivity to the rna1-1 mutant) suggests that release of HS RN Ps in the cytoplasm may occur through a different process or involve other components (for review, see Cole and Hammell 1998). The HS RN A export pathway is also independent of $\mathrm{N}$ pl 3p activity (Saavedra et al. 1997b).

In contrast, this pathway is sensitive to mutations in several other factors al so important for non-HS RN A export, such as the NUP genes RAT7/NUP159, RAT9/ NUP85, RAT2/NUP120, or RAT10/NUP145, and the transport gene GLE1/RSS1. Interestingly, HS RNA export is competed by high-level expression of wild-type Rev but not by an export-defective Rev mutant, suggesting that HS RN P export may depend on an NES (Saavedra et al. 1997b). Consistent with this possibility, HS 
RNA export is reduced in a temperature-sensitive CRM 1 mutant background (F. Stutz, unpubl.). Finally, HS RN P export under stress conditions absolutely requires the otherwise inessential FG-nucleoporin Riplp. In contrast, Gal 1 promoter-driven HS RN A s expressed at $25^{\circ} \mathrm{C}$ or HS RNAs induced at $37^{\circ} \mathrm{C}$ are exported through a pathway independent of Riplp (Saavedra et al. 1997b; Stutz et al. 1997), indicating that there is something special about the stress conditions rather than the transcript. The FG-repeat region of Riplp, initially identified as a Rev NES interacting region in a two-hybrid screen, was proposed more recently to interact with Rev NES via the bridging activity of the export factor Crmlp (Stutz et al. 1995; N eville et al. 1997; see above). Taken together, these data implied a dedicated role for the FG-repeat region of Riplp under stress, perhaps as a docking site for HS RN Ps. It turned out, however, that the unique carboxy-terminus of Riplp rather than its FG-repeat domain is essential for HS RNA export. The carboxyl terminal region of Riplp is al so able to rescue the synthetic lethality of GLE1 mutations and a RIP1 disruption, pointing to a parallel role of this domain in non-HS RN A export (Stutz et al. 1997). Although the function of this region is not yet understood, both genetic and two-hybrid data indicate that it physically interacts with Glelp (F. Stutz, unpubl.). We cannot exclude the possibility that Riplp may be involved in the reimport of factors essential for HS RN A export. As N LS-dependent import is apparently blocked under heat shock, these factors may be imported via one of the more recently identified N LS-independent pathways. This possibility al so applies to Glelp. However, we favor the notion that Riplp as well as Glelp optimize pore function for RNA export, especially for heat shock RNA export.

\section{Concluding remarks}

N umerous transport components have been identified, and many of them have been related to specific export or import phenotypes. With the exception of Ran and a few export and import receptors, however, the biochemical function of most of these components remains a mystery. The precise localization of a protein within the N PC, its assignment to specific subcomplexes, and its possible movements within or between pore substructures may bring additional clues to a precise role in transport. In the case of export, progress al so awaits an in vitro system that can be exploited for biochemical complementation.

\section{Acknowledgments}

We thank Iain M attaj, Elisa Izaurral de, Laura Davis, Hildur Colot, Christopher Hammell, Irena Vainberg, and Torben Heick Jensen for comments on the manuscript. Our thanks also go to Pam Silver, Laura Davis, Anita Hopper, Iain Mattaj, G. Simos, and Ed Hurt for sharing unpublished information.

\section{References}

A belson, J., C.R. Trotta, and H. Li. 1998. tRN A splicing. J. Biol. Chem. 273: 12685-12688.

Adam, E.J. and S.A. Adam. 1994. Identification of cytosolic factors required for nuclear location sequence-mediated binding to the nuclear envelope. J. Cell Biol. 125: 547-555.

Adam, S.A. and L. Gerace. 1991. Cytosolic proteins that specifically bind nuclear location signals are receptors for nuclear import. Cell 66: 837-847.

Alzhanova-Ericsson, A.T., X. Sun, N. Visa, E. Kiseleva, T. Wurtz, and B. Daneholt. 1996. A protein of the SR family of splicing factors binds extensively to exonic Bal biani ring premRNA and accompanies the RNA from the gene to the nuclear pore. Genes \& Dev. 10: 2881-2893.

Amberg, D.C., A.L. Goldstein, and C.N. Cole. 1992. Isolation and characterization of RAT1: An essential gene of Saccharomyces cerevisiae required for the efficient nucleocytoplasmic trafficking of mRNA. Genes \& Dev. 6: 11731189.

Arts, G.J., M. Fornerod, and I.W. M attaj. 1998. Identification of a nuclear export receptor for tRN A. Curr. Biol. 8: 305-314.

Bailer, S.M., S. Siniossoglou, A. Podtelejnikov, A. Hellwig, M. Mann, and E. Hurt. 1998. N up116p and N up100p are interchangeable through a conserved motif which constitutes a docking site for the mRN A transport factor Gle2p. EMBO J. 17: 1107-1119.

Bataille, N ., T. Helser, and H.M . Fried. 1990. Cytoplasmic transport of ribosomal subunits microinjected into the Xenopus laevis oocyte nucleus: A generalized, facilitated process. J. Cell Biol. 111: 1571-1582.

Belanger, K.D., M.A. Kenna, S. Wei, and L.I. Davis. 1994. Genetic and physical interactions between Srplp and nuclear pore complex proteins Nup1p and Nup2p. J. Cell Biol. 126: 619-630.

Bevec, D., H. Jaksche, M. Oft, T. Wohl, M. Himmelspach, A. Pacher, M. Schebesta, K. Koettnitz, M. Dobrovnik, R. Csonga, F. Lottspeich, and J. Hauber. 1996. Inhibition of HIV-1 replication in lymphocytes by mutants of the Rev cofactor elF-5A. Science 271: 1858-1860.

Birney, E., S. Kumar, and A.R. Krainer. 1993. Analysis of the RNA-recognition motif and RS and RGG domains: Conservation in metazoan pre-mRNA splicing factors. Nucleic Acids Res. 21: 5803-5816.

Bischoff, F.R., H. Krebber, E. Smirnova, W.H. Dong, and H. Ponstingl. 1995. Coactivation of RanGTPase and inhibition of GTP dissociation by Ran GTP binding protin RanBP1. EMBO J. 14: 705-715.

Bogerd, H.P., R.A. Fridell, S. Madore, and B.R. Cullen. 1995. Identification of a novel cellular cofactor for the Rev/Rex class of retroviral regulatory proteins. Cell 82: 485-494.

Bogerd, H.P., R.A. Fridell, R.E. Benson, J. Hua, and B.R. Cullen. 1996. Protein sequence requirements for function of the human T-cell leukemia virus type 1 Rex nuclear export signal del ineated by a novel in vivo randomization-selection assay. Mol. Cell. Biol. 16: 4207-4214.

Bogerd, H.P., A. Echarri, T.M. Ross, and B.R. Cullen. 1998. Inhibition of HIV-1 Rev and HTLV-I Rex function, but not MPM V CTE activity, by a mutant human nucleoporin targeted to $\mathrm{Crm1}$. J. Virol. (in press).

Bossie, M.A., C. DeHoratius, G. Barcelo, and P. Silver. 1992. A mutant nuclear protein with similarity to RN A binding proteins interferes with nuclear import in yeast. Mol. Biol. Cell 3: 875-893.

Bray, M., S. Prasad, J.W. Dubay, E. Hunter, K.T. Jeang, D. Rekosh, and M.L. Hammarskjold. 1994. A small element from 
the M ason-Pfizer monkey virus genome makes human immunodeficiency virus type 1 expression and replication Revindependent. Proc. Natl. A cad. Sci. 91: 1256-1260.

Brown, J.A., A. Bharathi, A. Ghosh, W. Whalen, E. Fitzgerald, and R. Dhar. 1995. A mutation in the Schizosaccharomyces pombe rael gene causes defects in poly $(A)^{+}$RN A export and in the cytoskel eton. J. Biol. Chem. 270: 7411-7419.

Buchman, A.R. and P. Berg. 1988. Comparison of intron-dependent and intron-independent gene expression. Mol. Cell. Biol. 8: 4395-4405.

Caceres, J.F., G.R. Screaton, and A.R. Krainer. 1998. A specific subset of SR proteins shuttles continuously between the nucleus and the cytoplasm. Genes \& Dev. 12: 55-66.

Chang, D.D. and P.A. Sharp. 1989. Regulation by HIV Rev depends upon recognition of splice sites. Cell 59: 789-795.

Chi, N.C., E.J.H. Adam, and S.A. Adam. 1997. Different binding domains for Ran-GTP and Ran-GDP/RanBP1 on nuclear import factor p97. J. Biol. Chem. 272: 6818-6822.

Cole, C.N. and C.M. Hammell. 1998. Nucleocytoplasmic transport: Driving and directing transport. Curr. Biol. 8: 368-372.

Corbett, A.H. and P.A. Silver. 1997. N ucleocytoplasmic transport of macromolecules. Microbiol. Mol. Biol. Rev. 61: 193211.

Cullen, B.R. and M.H. Malim. 1991. The HIV-1 rev protein: Prototype of a novel class of eukaryotic post-transcriptional regulators. Trends Biol. Sci. 16: 346-350.

Dahl berg, J.E. and E. Lund. 1998. Functions of the GTPase Ran in RNA export from the nucleus. Curr. Opin. Cell Biol. 10: 400-408.

Daneholt, B. 1997. A look at messenger RNP moving through the nuclear pore. Cell 88: 585-588.

Davis, L.I. 1995. The nuclear pore complex. Annu. Rev. Biochem. 64: 865-896.

Del Priore, V., C.A. Snay, A. Bahr, and C.N. Cole. 1996. The product of the Saccharomyces cerevisiae RSS1 gene, identified as a high-copy suppressor of the rat7-1 temperature sensitive allele of the RAT7/NUP159 nucleoporin, is re quired for efficient mRNA export. Mol. Biol. Cell 7: 16011621.

Doye, V. and E.C. Hurt. 1995. Genetic approaches to nuclear pore structure and function. Trends Genet. 11: 235-241.

- - - 1997. From nucleoporins to nuclear pore complexes. Curr. Opin. Cell Biol. 9: 401-411.

Eckner, R., W. Ellmeier, and M.L. Birnstiel. 1991. Mature mRNA $3^{\prime}$ end formation stimulates RNA export from the nucleus. EMBO J. 10: 3513-3522.

Fabre, E. and E. Hurt. 1997. Y east genetics to dissect the nuclear pore complex and nucleocytoplasmic trafficking. Annu. Rev. Genet. 31: 277-313.

Feinberg, M.B., R.F. Jarrett, A. Aldovini, R.C. Gallo, and F. Wong-Staal. 1986. HTLV-III expression and production involve complex regulation at the levels of splicing and translation of viral RNA. Cell 46: 807-817.

Felber, B.K., M. Hadzopoulou-Cladaras, C. Cladaras, T. Cope land, and G.N. Pavlakis. 1989. Rev protein of human immunodeficiency virus type 1 affects the stability and transport of the viral mRN A. Proc. Natl. Acad. Sci. 86: 1495-1499.

Fischer, U. and R. Lührmann. 1990. An essential signaling role for the $m_{3} G$ cap in the transport of $U 1$ snRN $P$ to the nucleus. Science 249: 786-790.

Fischer, U., J. Huber, W.C. Boelens, I.W. Mattaj, and R. Lührmann. 1995. The HIV-1 Rev activation domain is a nuclear export signal that accesses an export pathway used by specific cellular RNAs. Cell 82: 475-483.

Fischer, U., V. Sumpter, M. Sekine, T. Satoh, and R. Lührmann.
1993. N ucleo-cytoplasmic transport of U snRN Ps: Definition of a nuclear location signal in the Sm core domain that binds a transport receptor independently of the $\mathrm{m3G}$ cap. EMBO J. 12: 573-583.

Fischer, U., S. Meyer, M. Teufel, C. Heckel, R. Lührmann, and G. Rautmann. 1994. Evidence that HIV-1 Rev directly promotes the nuclear export of unspliced RNA. EMBO J. 13: 4105-4112.

Flach, J., M. Bossie, J. Vogel, A. Corbett, T. Jinks, D.A. Willins, and P.A. Silver. 1994. A yeast RN A-binding protein shuttles between the nucleus and the cytoplasm. Mol. Cell. Biol. 14: 8399-8407.

Fornerod, M., M. Ohno, M. Yoshida, and I.W. Mattaj. 1997a. CRM 1 is an export receptor for leucine-rich nuclear export signals. Cell 90: 1051-1060.

Fornerod, M., J. van Deursen, S. van Baal, A. Reynolds, D. Davis, K.G. Murti, J. Fransen, and G. Grosveld. 1997b. The human homologue of yeast CRM 1 is in a dynamic subcomplex with CAN / N up214 and a novel nuclear pore component N up88. EMBO J. 16: 807-816.

Fritz, C.C., M.L. Zapp, and M .R. Green. 1995. A human nucleoporin-like protein that specifically interacts with HIV Rev. Nature 376: 530-533.

Fukuda, M., S. A sano, T. N akamura, M. Adachi, M. Yoshida, M. Yanagida, and E. Nishida. 1997. CRM 1 is responsible for intracellular transport mediated by the nuclear export signal. Nature 390: 308-311.

Görlich, D. 1997. N uclear protein import. Curr. Opin. Cell Biol. 9: 412-419.

- - . 1998. Transport into and out of the cell nucleus. EMBO J. 17: 2721-2727.

Görlich, D. and I.W. Mattaj. 1996. Nucleocytoplasmic transport. Science 271: 1513-1518.

Görlich, D., S. Prehn, R.A. Laskey, and E. Hartmann. 1994. IsoIation of a protein that is essential for the first step of nuclear protein import. Cell 79: 767-778.

Görlich, D., S. Kostka, R. Kraft, C. Dingwall, R.A. Laskey, E. Hartmann, and S. Prehn. 1995a. Two different subunits of importin cooperate to recognize nuclear localization signals and bind them to the nuclear envelope. Curr. Biol. 5: 383392.

Görlich, D., F. Vogel, A.D. M ills, E. Hartmann, and R.A. Laskey. 1995b. Distinct functions for the two importin subunits in nuclear protein import. Nature 377: 246-248.

Görlich, D., N. Pante, U. Kutay, U. Aebi, and F.R. Bischoff. 1996. Identification of different roles for RanGDP and RanGTP in nuclear protein import. EMBO J. 15: 5584-5594.

Görlich, D., M. Dabrowski, F.R. Bischoff, U. Kutay, P. Bork, E. Hartmann, S. Prehn, and E. Izaurral de. 1997. A novel class of RanGTP binding proteins. J. Cell Biol. 138: 65-80.

Grandi, P., V. Doye, and E.C. Hurt. 1993. Purification of N SP1 reveals complex formation with 'GLFG' nucleoporins and a novel nuclear pore protein NIC96. EMBO J. 12: 3061-3071.

Grüter, P., C. Tabernero, C. von Kobbe, C. Schmitt, C. Saavedra, A. Bachi, M. Wilm, B.K. Fel ber, and E. Izaurral de. 1998. TAP, the human homolog of Mex67p, mediates CTE-dependent RN A export from the nucleus. Mol. Cell 1: 649-659.

Guan, T., S. Muller, G. Klier, N. Pante, J.M. Blevitt, Haner, B. Paschal, U. A ebi, and L. Gerace. 1995. Structural analysis of the p62 complex, an assembly of O-linked glycoproteins that localizes near the central gated channel of the nuclear pore complex. Mol. Biol. Cell 6: 1591-1603.

Hadzopoulou-Cladaras, M., B.K. Fel ber, C. Cladaras, A. Athanassopoulos, A. Tse, and G.N. Pavlakis. 1989. The rev (trs/ art) protein of human immunodeficiency virus type 1 affects viral mRNA and protein expression via a cis-acting sequence 
in the env region. J. Virol. 63: 1265-1274.

Hakata, Y., T. Umemoto, S. M atsushita, and H. Shida. 1998. Involvment of human CRM 1 (Exportin 1) in the export and multimerization of the Rex protein of human T-cell leukemia virus type 1. J. Virol. 72: 6602-6607.

Hamm, J. and I.W. Mattaj. 1990. Monomethylated cap structures facilitate RN A export from the nucleus. Cell 63: 109118.

Hamm, J., E. Darzynkiewicz, S.M. Tahara, and I.W. Mattaj. 1990a. The trimethylguanosine cap structure of U 1 snRN A is a component of a bipartite nuclear targeting signal. Cell 62: 569-577.

Heaphy, S., C. Dingwall, I. Ernberg, M.J. Gait, S.M. Green, J. Karn, A.D. Lowe, M. Singh, and M.A. Skinner. 1990. HIV-1 regulator of virion expression (Rev) protein binds to an RN A stem-loop structure located within the Rev response ele ment region. Cell 60: 685-693.

Heaphy, S., J.T. Finch, M.J. Gait, J. Karn, and M. Singh. 1991. Human immunodeficiency virus type 1 regulator of virion expression, rev, forms nucleoprotein filaments after binding to a purine-rich 'bubble' located within the rev-responsive region of viral mRNAs. Proc. Natl. Acad. Sci. 88: 73667370.

Henry, M.F. and P.A. Silver. 1996. A novel methyltransferase (Hmtlp) modifies poly(A)+-RN A-binding proteins. Mol. Cell. Biol. 16: 3668-3678.

Henry, M., C.Z. Borland, M. Bossie, and P.A. Silver. 1996. Potential RNA binding proteins in Saccharomyces cerevisiae identified as suppressors of temperature-sensitive mutations in N PL3. Genetics 142: 103-115.

Hopper, A.K., L.D. Schultz, and R.A. Shapiro. 1980. Processing of intervening sequences: $A$ new yeast mutant which fails to excise intervening sequences from precursor tRNAs. Cell 19: 741-751.

Hopper, A.K., H.M. Traglia, and R.W. Dunst. 1990. The yeast RNA1 gene product necessary for RN A processing is located in the cytosol and apparently excluded from the nucleus. J. Cell Biol. 111: 309-321.

Huang, Y. and G.G. Carmichael. 1997. The mouse histone H2a gene contains a small element that facilitates cytoplasmic accumulation of intronless gene transcripts and of unspliced HIV-1-related mRNAs. Proc. Natl. Acad. Sci. 94: 1010410109.

Hurt, D.J., S.S. Wang, Y.H. Lin, and A.K. Hopper. 1987. Cloning and characterization of LOS1, a Saccharomyces cerevisiae gene that affects tRNA splicing. Mol. Cell. Biol. 7: 12081216.

Imamoto, N ., T. Tachibana, M. M atsubae, and Y. Yoneda. 1995. A karyophilic protein forms a stable complex with cytoplasmic components prior to nuclear pore binding. J. Biol. Chem. 270: 8559-8565.

Iovine, M.K., J.L. Watkins, and S.R. Wente. 1995. The GLFG repetitive region of the nucleoporin $\mathrm{N}$ up116p interacts with Kap95p, an essential yeast nuclear import factor. J. Cell Biol. 131: 1699-1713.

Izaurralde, E. and S. Adam. 1998. Transport of macromolecules between the nucleus and the cytoplasm. RNA 4: 351364.

Izaurral de, E., J. Stepinski, E. Darzynkiewicz, and I.W. Mattaj. 1992. A cap binding protein that may mediate nuclear export of RNA polymerase II-transcribed RNAs. J. Cell Biol. 118: $1287-1295$.

Izaurral de, E., J. Lewis, C. Gamberi, A. Jarmolowski, C. M cGuigan, and I.W. Mattaj. 1995. A cap-binding protein complex mediating U snRN A export. Nature 376: 709-712.

Izaurral de, E., A. Jarmolowski, C. Beisel, I.W. Mattaj, G. Drey- fuss, and U. Fischer. 1997a. A rolefor the M 9 transport signal of hnRN P A1 in mRN A nuclear export. J. Cell Biol. 137: 2735.

Izaurralde, E., U. Kutay, C. von Kobbe, I.W. Mattaj, and D. Görlich. 1997b. The asymmetric distribution of the constituents of the Ran system is essential for transport into and out of the nucleus. EMBO J. 16: 6535-6547.

Jarmolowski, A., W.C. Boelens, E. Izaurral de, and I.W. Mattaj. 1994. N uclear export of different classes of RN A is mediated by specific factors. J. Cell Biol. 124: 627-635.

Kadowaki, T., Y. Zhao, and A.M. Tartakoff. 1992. A conditional yeast mutant deficient in mRNA transport from nucleus to cytoplasm. Proc. Natl. Acad. Sci. 89: 23122316.

Kessler, M.M., M.F. Henry, E. Shen, J. Zhao, S. Gross, Silver, PA, and C.L. Moore. 1997. Hrpl, a sequence-specific RNA-binding protein that shuttles between the nucleus and the cytoplasm, is required for mRNA 3 '-end formation in yeast. Genes \& Dev. 11: 2545-2556.

Kiseleva, E., M.W. Goldberg, B. Daneholt, and T.D. Allen. 1996. RNP export is mediated by structural reorganization of the nuclear pore basket. J. Mol. Biol. 260: 304-311.

Kjems, J. and P.A. Sharp. 1993. The basic domain of rev from human immunodeficiency virus type 1 specifically blocks the entry of U4/U6 U 5 small nuclear ribonucleoprotein in spliceosome assembly. J. Virol. 67: 4769-4776.

Kjems, J., A.D. Frankel, and P.A. Sharp. 1991. Specific regulation of mRN A splicing in vitro by a peptide from HIV-1 Rev. Cell 67: 169-178.

Koepp, D.M. and P.A. Silver. 1996. A GTPase controlling nuclear trafficking: Running the right way or walking randomly. Cell 87: 1-4.

Kraemer, D. and G. Blobel. 1997. mRN A binding protein mrnp 41 localizes to both nucleus and cytoplasm. Proc. Natl. Acad. Sci. 94: 9119-9124.

Kraemer, D.M., C. Strambio-de-Castillia, G. Blobel, and M.P. Rout. 1995. The essential yeast nucleoporin NUP159 is Iocated on the cytoplasmic side of the nuclear pore complex and serves in karyopherin-mediated binding of transport substrate. J. Biol. Chem. 270: 19017-19021.

Kutay, U., F.R. Bischoff, S. Kostka, R. Kraft, and D. Görlich. 1997. Export of importin $\alpha$ from the nucleus is mediated by a specific nuclear transport factor. Cell 90: 1061-1071.

Kutay, U., G. Lipowsky, E. Izaurral de, F.R. Bischoff, P. Schwarzmaier, E. Hartmann, and D. Görlich. 1998. Identification of a tRN A-specific nuclear export receptor. Mol. Cell 1: 359369.

Lee, M.S., M. Henry, and P.A. Silver. 1996. A protein that shuttles between the nucleus and the cytoplasm is an important mediator of RNA export. Genes \& Dev. 10: 12331246.

Liang, S., M. Hitomi, Y.H. Hu, Y. Liu, and A.M. Tartakoff. 1996. A DEAD-box-family protein is required for nucleocytoplasmic transport of yeast mRNA. Mol. Cell. Biol. 16: 51395146.

Liu, Q. and G. Dreyfuss. 1995. In vivo and in vitro arginine methylation of RNA-binding proteins. Mol. Cell. Biol. 15: 2800-2808.

Liu, X. and J.E. Mertz. 1995. HnRN P L binds a cis-acting RN A sequence element that enables intron-dependent gene expression. Genes \& Dev. 9: 1766-1780.

Malim, M.H. and B.R. Cullen. 1993. Rev and the fate of premRNA in the nucleus: Implications for the regulation of RNA processing in eukaryotes. Mol. Cell. Biol. 13: 61806189.

Malim, M.H., S. Böhnlein, J. Hauber, and B.R. Cullen. 1989a. 
Functional dissection of the HIV-1 Rev trans-activatorderivation of a trans-dominant repressor of Rev function. Cell 58: 205-214.

Malim, M.H., J. Hauber, S.-Y. Le, J.V. Maizel, and B.R. Cullen. 1989b. The HIV-1 Rev trans-activator acts through a structured target sequence to activate nucl ear export of unspliced viral mRN A. Nature 338: 254-257.

Malim, M.H., L.S. Tiley, D.F. McCarn, J.R. Rusche, J. Hauber, and B.R. Cullen. 1990. HIV-1 structural gene expression re quires binding of the Rev trans-activator to its RNA target sequence. Cell 60: 675-683.

Malim, M.H., D.F. McCarn, L.S. Tiley, and B.R. Cullen. 1991. Mutational definition of the human immunodeficiency virus type I Rev activation domain. J. Virol. 65: 42484254.

M attaj, I.W. and L. Englmeier. 1998. N ucleocytoplasmic transport: The soluble phase. Annu. Rev. Biochem. 67: 265-306.

M atunis, E.L., M.J. M atunis, and G. Dreyfuss. 1993. Association of individual hnRNP proteins and snRNPs with nascent transcripts. J. Cell Biol. 121: 219-228.

Mehlin, H., B. Daneholt, and U. Skogl und. 1992. Translocation of a specific premessenger ribonucleoprotein particle through the nuclear pore studied with electron microscope tomography. Cell 69: 605-613.

Michael, M.W., M. Choi, and G. Dreyfuss. 1995. A nuclear export signal in hnRNP A1: A signal-mediated, temperature dependent nuclear protein export pathway. Cell 83: 415-422.

Michael, W.M., P.S. Eder, and G. Dreyfuss. 1997. The K nuclear shuttling domain: A novel signal for nuclear import and nuclear export in the hnRN P K protein. EMBO J. 16: 35873598.

Moroianu, J., M. Hijikata, G. Blobel, and A. Radu. 1995. Mammal ian karyopherin $\alpha 1 \beta$ and $\alpha 2 \beta$ heterodi mers: $\alpha 1$ or $\alpha 2$ subunit binds nuclear local ization signal and $\beta$ subunit interacts with peptide repeat-containing nucleoporins. Proc. Natl. Acad. Sci. 92: 6532-6536.

Murphy, R. and S.R. Wente. 1996. An RNA-export mediator with an essential nuclear export signal. Nature 383: 357360.

Murphy, R., J.L. Watkins, and S.R. Wente. 1996. GLE2, a Saccharomyces cerevisiae homologue of the Schizosaccharomyces pombe export factor RAE1, is required for nuclear pore complex structure and function. Mol. Biol. Cell 7: 1921-1937.

Nakielny, S. and G. Dreyfuss. 1996. The hnRNP C proteins contain a nuclear retention sequence that can override nuclear export signals. J. Cell Biol. 134: 1365-1373.

- - . 1997. N uclear export of proteins and RN As. Curr. O pin. Cell Biol. 9: 420-429.

N akielny, S., U. Fischer, W.M. Michael, and G. Dreyfuss. 1997. RN A transport. Annu. Rev. Neurosci. 20: 269-301.

Neville, M., F. Stutz, L. Lee, L.I. Davis, and M. Rosbash. 1997. Evidence that the importin-beta family member Crmlp bridges the interaction between Rev and the nuclear pore complex during nuclear export in S. cerevisiae. Curr. Biol. 7: 767-775.

Nigg, E.A. 1997. N ucleocytoplasmic transport: Signals, mechanisms and regulation. Nature 386: 779-787.

Nishi, K., M. Yoshida, D. Fujiwara, M. Nishikawa, S. Horinouchi, and T. Beppu. 1994. Leptomycin B targets a regulatory cascade of crm1, a fission yeast nuclear protein, involved in control of higher order chromosome structure and gene expression. J. Biol. Chem. 269: 6320-6324.

N oble, S.M. and C. Guthrie. 1996. Identification of novel genes required for yeast pre-mRNA splicing by means of cold-sen- sitive mutations. Genetics 143: 67-80.

Ohtsubo, M., H. Okazaki, and T. N ishimoto. 1989. The RCC1 protein, a regulator for the onset of chromosome condensation, locates in the nucleus and binds to DN A. J. Cell Biol. 109: 1389-1397.

Ossareh-N azari, B., F. Bachelerie, and C. Dargemont. 1997. Evidence for a role of CRM 1 in signal-mediated nuclear protein export. Science 278: 141-144.

Pante, N. and U. Aebi. 1996a. Molecular dissection of the nuclear pore complex. Crit. Rev. Biochem. Mol. Biol. 31: 153-199.

-_- 1996b. Toward the molecular dissection of protein import into nuclei. Curr. Opin. Cell Biol. 8: 397-406.

Pasquinelli, A.E., R.K. Ernst, E. Lund, C. Grimm, M.L. Zapp, D. Rekosh, M.L. Hammarskjold, and J.E. Dahl berg. 1997a. The constitutive transport el ement (CTE) of M ason-Pfizer monkey virus (MPMV) accesses a cellular mRNA export pathway. EMBO J. 16: 7500-7510.

Pasquinelli, A.E., M.A. Powers, E. Lund, D. Forbes, Dahlberg, and JE. 1997b. Inhibition of mRN A export in vertebrate cells by nuclear export signal conjugates. Proc. Natl. Acad. Sci. 94: 14394-14399.

Pemberton, L.F., G. Blobel, and J.S. Rosenblum. 1998. Transport routes through the nuclear pore complex. Curr. Opin. Cell Biol. 10: 392-399.

Piñol-Roma, S. and G. Dreyfuss. 1992. Shuttling of pre-mRNA binding proteins between nucleus and cytoplasm. Nature 355: 730-732.

Pokrywka, N.J. and D.S. Goldfarb. 1995. Nuclear export pathways of tRN $A$ and 40 S ribosomes include both common and specific intermediates. J. Biol. Chem. 270: 3619-3624.

Pollard, V.W., W.M. Michael, S. N akielny, M.C. Siomi, F. Wang, and G. Dreyfuss. 1996. A novel receptor-mediated nuclear protein import pathway. Cell 86: 985-994.

Radu, A., G. Blobel, and M.S. M oore. 1995a. Identification of a protein complex that is required for nuclear protein import and mediates docking of import substrate to distinct nucleoporins. Proc. Natl. Acad. Sci. 92: 1769-1773.

Radu, A., M.S. M oore, and G. Blobel. 1995b. The peptide repeat domain of nucleoporin Nup98 functions as a docking site in transport across the nuclear pore complex. Cell 81: 215222.

Rexach, M. and G. Blobel. 1995. Protein import into nuclei: Association and dissociation reactions involving transport substrate, transport factors, and nucleoporins. Cell 83: 683692.

Richards, S.A., K.M. Lounsbury, K.L. Carey, and I.G. Macara. 1996. A nuclear export signal is essential for the cytosolic localization of the Ran binding protein, RanBP1. J. Cell Biol. 134: 1157-1168.

Richards, S.A., K.L. Carey, and I.G. Macara. 1997. Requirement of guanosine triphosphate-bound Ran for signal-mediated nuclear protein export. Science 276: 1842-1844.

Rout, M.P. and G. Blobel. 1993. Isolation of the yeast nuclear pore complex. J. Cell Biol. 123: 771-783.

Rout, M.P. and S.R. Wente. 1994. Pores for thought: Nuclear pore complex proteins. Trends Cell Biol. 4: 357-365.

Ruhl, M., M. Himmelspach, G.M. Bahr, F. Hammerschmid, H. Jaksche, B. Wolff, H. Aschauer, G.K. Farrington, H. Probst, D. Bevec, and J. Hauber. 1993. Eukaryotic initiation factor $5 \mathrm{~A}$ is a cellular target of the human immunodeficiency virus type 1 Rev activation domain mediating trans-activation. J. Cell Biol. 123: 1309-1320.

Russell, I.D. and D. Tollervey. 1992. N OP3 is an essential yeast protein which is required for pre-rRNA processing. J. Cell Biol. 119: 737-747. 
Saavedra, C., K.-S. Tung, D.C. A mberg, A.K. Hopper, and C.N . Cole. 1996. Regulation of mRN A export in response to stress in Saccharomyces cerevisiae. Genes \& Dev. 10: 1608-1620.

Saavedra, C., B. Felber, and E. Izaurral de. 1997a. The simian retrovirus-1 constitutive transport element, unlike the HIV-1 RRE, utilises factors required for the export of cellular mRN As. Curr. Biol. 7: 619-628.

Saavedra, C.A., C.M. Hammell, C.V. Heath, and C.N. Cole 1997b. Export of heat shock mRNAs following stress in Saccharomyces cerevisiae employs a distinct pathway defined by Riplp and al so requires a subset of factors essential for export of poly $(A)^{+}$mRN A. Genes \& Dev. 11: 28452856.

Sarkar, S. and A.K. Hopper. 1998. tRN A nuclear export in S. cerevisiae: In situ hybridization analysis. Mol. Biol. Cell 9: (in press).

Schatz, O., M. Oft, C. Dascher, M. Schebesta, O. Rosorius, H. Jaksche, M. Dobrovnik, D. Bevec, and J. Hauber. 1998. Interaction of the HIV-1 Rev cofactor eukaryotic initiation factor 5A with ribosomal protein L5. Proc. Natl. Acad. Sci. 95: 1607-1612.

Schlenstedt, G., D.H. Wong, D.M. Koepp, and P.A. Silver. 1995. Mutants in a yeast Ran binding protein are defective in nuclear transport. EMBO J. 14: 5367-5378.

Segref, A., K. Sharma, V. Doye, A. Hellwig, J. Huber, R. Luhrmann, and E. Hurt. 1997. M ex67p, a novel factor for nuclear mRNA export, binds to both poly $(\mathrm{A})^{+} \mathrm{RNA}$ and nuclear pores. EMBO J. 16: 3256-3271.

Shah, S., S. Tugendreich, and D. Forbes. 1998. Major binding sites for the nuclear import receptor are the internal nucleoporin N up153 and the adjacent nucl ear filament protein T pr. J. Cell Biol. 141: 31-49.

Shen, E.C., M.F. Henry, V.H. Weiss, S.R. Valentini, P.A. Silver, and M.S. Lee. 1998. Arginine methylation facilitates the nuclear export of hnRNP proteins. Genes \& Dev. 12: 679691.

Shulga, N., P. Roberts, Z. Gu, L. Spitz, M.M. Tabb, M. N omura, and D.S. Goldfarb. 1996. In vivo nuclear transport kinetics in Saccharomyces cerevisiae: A role for heat shock protein 70 during targeting and translocation. J. Cell Biol. 135: 329339.

Simos, G., H. Tekotte, H. Grosjean, A. Segref, K. Sharma, D. Tollervey, and E.C. Hurt. 1996. Nuclear pore proteins are involved in the biogenesis of functional tRNA. EMBO J. 15: $2270-2284$.

Singleton, D.R., S. Chen, M. Hitomi, C. Kumagai, and A.M. Tartakoff. 1995. A yeast protein that bidirectionally affects nucleocytoplasmic transport. J. Cell Sci. 108: 265-272.

Siniossogl ou, S., C. Wimmer, M. Rieger, V. Doye, H. Tekotte, C. Weise, S. Emig, A. Segref, and E.C. Hurt. 1996. A novel complex of nucleoporins, which includes Sec13p and a Sec13p homolog, is essential for normal nuclear pores. Cell 84: 265275.

Siomi, M.C., P.S. Eder, N. Kataoka, L. Wan, Q. Liu, and G. Dreyfuss. 1997. Transportin-mediated nuclear import of heterogeneous nuclear RNP proteins. J. Cell Biol. 138: 11811192.

Snay-Hodge, C.A., H.V. Colot, A.L. Goldstein, and C.N. Cole 1998. Dbp5p/Rat8p is a yeast nuclear pore-associated DEAD-box protein essential for RNA export. EMBO J. 17: 2663-2676.

Sodroski, J., W.C. Goh, C. Rosen, A. Dayton, E. Terwilliger, and W. Haseltine. 1986. A second post-transcriptional trans-activator gene required for HTLV-III replication. Nature 321: 412-417.

Stade, K., C.S. Ford, C. Guthrie, and K. Weis. 1997. Exportin 1
(Crm1p) is an essential nuclear export factor. Cell 90: 10411050.

Stutz, F. and M. Rosbash. 1994. A functional interaction between Rev and yeast pre-mRNA is related to splicing complex formation. EMBO J. 13: 4096-4104.

Stutz, F., M. N eville, and M. Rosbash. 1995. Identification of a novel nuclear pore-associated protein as a functional target of the HIV-1 Rev protein in yeast. Cell 82: 495-506.

Stutz, F., E. Izaurral de, I.W. Mattaj, and M. Rosbash. 1996. A role for nucleoporin FG repeat domains in export of human immunodeficiency virus type 1 Rev protein and RN A from the nucleus. Mol. Cell. Biol. 16: 7144-7150.

Stutz, F., J. Kantor, D. Zhang, T. M cCarthy, M. N eville, and M. Rosbash. 1997. The yeast nucleoporin Riplp contributes to multiple export pathways with no essential role for its FGrepeat region. Genes \& Dev. 11: 2857-2868.

Stutz, F., J. Tang, and M. Rosbash. 1998. Synthetic lethal/enhancer screening to identify snRN A-protein and protein-protein interactions in yeast pre-mRNA splicing. In RNA: Protein interactions. A practical approach (ed. C.W.J. Smith), pp. 161-182. Oxford University Press, Oxford, UK.

Tabernero, C., A.S. Zolotukhin, J. Bear, R. Schneider, G. Karsenty, and B.K. Felber. 1997. Identification of an RNA sequence within an intracisternal-A particle el ement able to replace Rev-mediated posttranscriptional regulation of human immunodeficiency virus type 1. J. Virol. 71: 95-101.

Toone, M.W., S. Kuge, M. Samuels, B.A. M organ, T. Toda, and N. Jones. 1998. Regulation of the fission yeast transcription factor Papl by oxidative stress: Requirement for the nuclear export factor $\mathrm{Crm} 1$ (Exportin) and the stress-activated M AP kinase Sty1/Spc1. Genes \& Dev. 12: 1453-1463.

Tseng, S.I., P.L. Weaver, Y. Liu, M . Hitomi, A.M. Tartakoff, and T.H. Chang. 1998. Dbp5p, a cytosolic RN A helicase, is required for poly(A) ${ }^{+}$RN A export. EMBO J. 17: 2651-2662.

Ullman, K.S., M.A. Powers, and D.J. Forbes. 1997. N uclear export receptors: From importin to exportin. Cell 90: 967970.

Visa, N ., A.T. Alzhanova-Ericsson, X. Sun, E. Kiseleva, B. Bjorkroth, T. Wurtz, and B. Daneholt. 1996a. A pre-mRN A-binding protein accompanies the RN A from the gene through the nuclear pores and into polysomes. Cell 84: 253-264.

Visa, N., E. Izaurral de, J. Ferreira, B. Daneholt, and I.W. Mattaj. 1996b. A nuclear cap-binding complex binds balbiani ring pre-mRN A cotranscriptionally and accompanies the ribonucleoprotein particle during nuclear export. J. Cell Biol. 133: 5-14.

Watkins, J.L., R. Murphy, J.L. Emtage, and S.R. Wente. 1998. The human homolog of Saccharomyces cerevisiae Glelp is required for poly(A) ${ }^{+}$RNA export. Proc. Natl. Acad. Sci. 95: 6779-6784.

Weis, K. 1998. Importins and exportins: How to get in and out of the nucleus. Trends Biochem. Sci. 23: 185-189.

Weis, K., I.W. Mattaj, and A.I. Lamond. 1995. Identification of hSRP $1 \alpha$ as a functional receptor for nuclear localization se quences. Science 268: 1049-1053.

Wen, W., J.L. M einkoth, R.Y. Tsien, and S.S. Taylor. 1995. Identification of a signal for rapid export of proteins from the nucleus. Cell 82: 463-473.

Wente, S.R. and G. Blobel. 1993. A temperature-sensitive NUP116 null mutant forms a nuclear envel ope seal over the yeast nuclear pore complex thereby blocking nucleocytoplasmic traffic. J. Cell Biol. 123: 275-284.

Wilson, S.M., K.V. Datar, M.R. Paddy, J.R. Swedlow, and M.S Swanson. 1994. Characterization of nuclear polyadenylated RN A-binding proteins in Saccharomyces cerevisiae. J. Cell Biol. 127: 1173-1184. 
Wimmer, C., V. Doye, P. Grandi, U. N ehrbass, and E.C. Hurt. 1992. A new subclass of nucleoporins that functionally interact with nuclear pore protein NSP1. EMBO J. 11: 50515061.

Wolff, B., J.-J. Sanglier, and Y. Wang. 1997. Leptomycin B is an inhibitor of nuclear export: Inhibition of nucleo-cytoplasmic translocation of the human immunodeficiency virus type 1 (HIV-1) Rev protein and Rev-dependent mRNA. Chem. \& Biol. 4: 139-147.

Wozniak, R.W., M.P. Rout, and J.D. Aitchison. 1998. Karyopherins and kissing cousins. Trends Cell Biol. 8: 184188.

Zapp, M.L. and M.R. Green. 1989. Sequence-specific RN A binding by the HIV-1 Rev protein. Nature 342: 714-716.

Zapp, M.L., T.J. Hope, T.G. Parslow, and M.R. Green. 1991. Oligomerization and RNA binding domains of the type 1 human immunodeficiency virus Rev protein: A dual function for an arginine-rich binding motif. Proc. Natl. Acad. Sci. 88: 7734-7738.

Zasl off, M. 1983. tRN A transport from the nucleus in a eukaryotic cell: Carrier-mediated translocation process. Proc. Natl. Acad. Sci. 80: 6436-6440. 


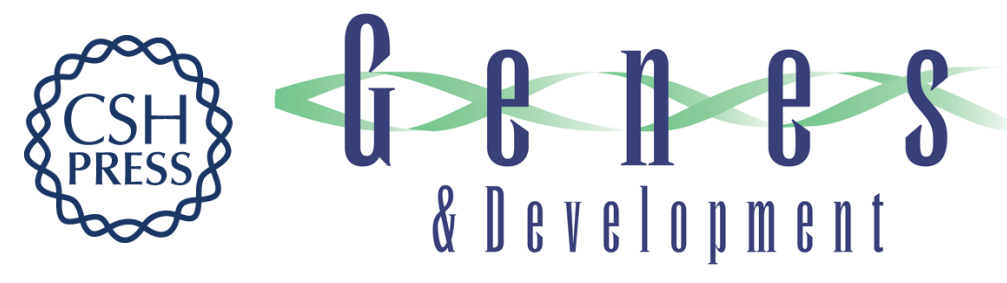

\section{Nuclear RNA export}

Françoise Stutz and Michael Rosbash

Genes Dev. 1998, 12:

Access the most recent version at doi:10.1101/gad.12.21.3303

References This article cites 163 articles, 91 of which can be accessed free at: http://genesdev.cshlp.org/content/12/21/3303.full.html\#ref-list-1

License

Email Alerting Receive free email alerts when new articles cite this article - sign up in the box at the top Service right corner of the article or click here.

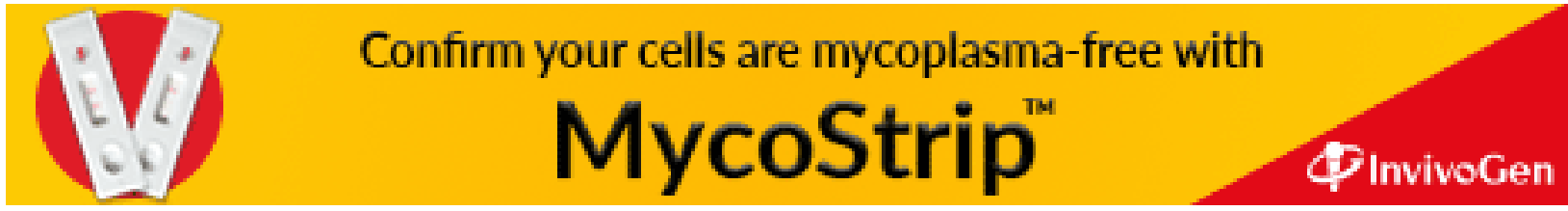

